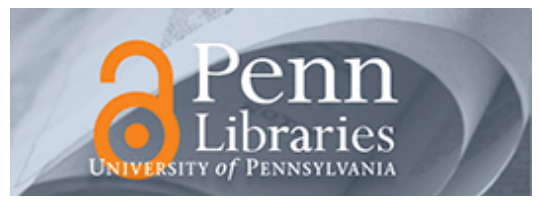

Studies in Visual Communication

Volume 4

Issue 2 Winter 1977

Article 7

1977

\title{
The Potters and the Painters: Art by and About Women in Urban Africa
}

Bennetta Jules-Rosette

\section{Recommended Citation}

Jules-Rosette, B. (1977). The Potters and the Painters: Art by and About Women in Urban Africa. 4 (2), 112-127. Retrieved from https://repository.upenn.edu/svc/vol4/iss $2 / 7$

This paper is posted at ScholarlyCommons. https://repository.upenn.edu/svc/vol4/iss2/7

For more information, please contact repository@pobox.upenn.edu. 
The Potters and the Painters: Art by and About Women in Urban Africa 


\section{THE POTTERS AND THE PAINTERS: ART BY AND ABOUT WOMEN IN URBAN AFRICA}

\section{BENNETTA JULES-ROSETTE}

Art, like other cultural products, reflects the hierarchical structure and division of labor in society. The history of women in Western art from the 16th century to the present has been characterized by both cultural and social structural barriers to the mainstream of art production (Tuchman 1975:171-202). While the limitations are not as rigid in the West as they have been in Central African traditional and popular art, the gender-linked distinctions in the African case provide fundamental insights for a cross-cultural understanding of the changing position of women in the arts.

The variety of cultural forms found in popular African art offers a key for deciphering the relationship between social life and symbolic behavior. The characteristics of art by and about women will be approached through linking cultural perceptions to the process of art production. Therefore, I shall discuss both images of men in women's art and the portrayal of women in popular African carving and painting.

The contemporary artists of Lusaka, Zambia, are a diverse group ethnically and economically. One of their major characteristics is differentiation along sexual lines. These distinctions have their roots in traditional African art and in the ritual requirements and prohibitions placed on women in this domain. Traditionally, in Central Africa, women worked with soft materials such as clay and textiles. Figures 1-3 contain examples of women's pottery found among the Bemba of Zambia.

Much of the traditional pottery production of the Bemba and other Zambian artists was associated with young women's initiation rites generally termed chisungu. The pottery emblems or mbusa (Figure 2) were figures used by the older women to instruct the initiates in familial and household responsibilities. Only women were allowed to see these figures. Carved figures that played important roles as symbols of political and social solidarity were, on the contrary, intended to be made and viewed only by men. ${ }^{1}$ The segregation of the sexes in work and ritual life in many African societies has markedly influenced not only traditional African art but also the newer art forms.

Bennetta Jules-Rosette is an Assistant Professor of Sociology at the University of California, San Diego. She has been engaged in research in African religious and artistic movements for a number of years. Her most recent publication entitled A Paradigm for Looking was co-authored with Beryl Bellman.

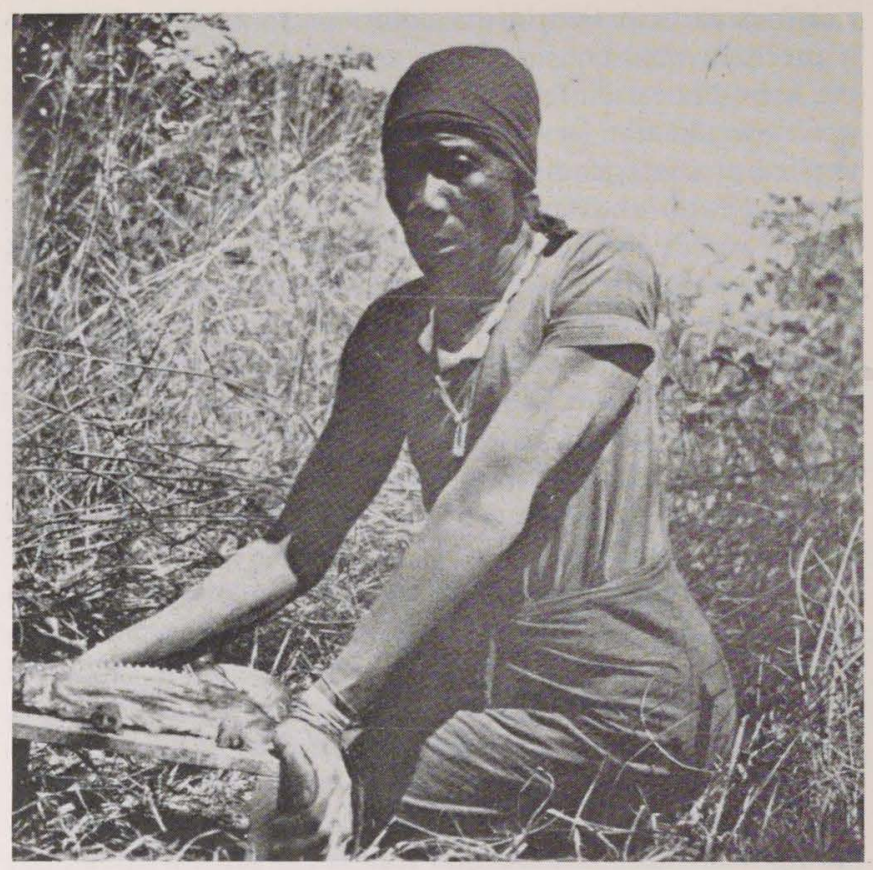

Figure $1-A$ Bemba nacimbusa or head initiator displays a crocodile figurine, symbolizing male domestic power and the secrets of the household, during the chisungu initiation ceremony (Richards 1956:80, 102).

This analysis does not make a strong distinction between popular and "airport" art. Rather, it includes in the category of popular art a broad spectrum of works produced for tourist and community consumption in the urban sector. I shall not focus on a classification of artistic styles, but instead shall examine the process of artistic production as a structured activity, as a vehicle of individual creativity, and as an indicator of broader social relationships. This work varies in terms of the level of expertise possessed by the artists, their training, which ranges from informal apprenticeship to government schooling, and their target audiences. The popular artists of Lusaka are in search of an audience. They often have mixed outlets, including African proletarian, local elite, and tourist groups.

My research on African art began as a larger study of social networks in the shanty areas surrounding Lusaka, Zambia's capital. Initially, I was interested in small cottage industries and self-employment. The artists appeared among the most visible and creative members of the self-employed population in several shanty areas. Almost immediately, I noticed the absence of women among the more lucrative commercial artists, despite a definite emphasis on images of women in their art. Women, however, were prominent among the producers of pottery consumed within the shanty communities. This difference led me to an interest in the ethnographic and symbolic differences between women's and men's art in urban Zambia. The strongest distinction emerged between artworks by women and artworks made about women by men. Men have made a more radical transition in the social organization and style of art production, while women have remained more limited by existing definitions of accepted activity. However, despite male artists' attempts to define new cultural goals, their images of women remain rela- 
tively static and do not portray the contemporary woman's experience.

Over the past three years, I have interviewed 65 artists in Lusaka's shanty towns. Among them, I have worked in depth with four principal informants, including three painters and one potter. These artists have spent long hours discussing their métier with me and have allowed me to experiment with using their materials. During the course of this work, the importance of gender-linked distinctions in African art

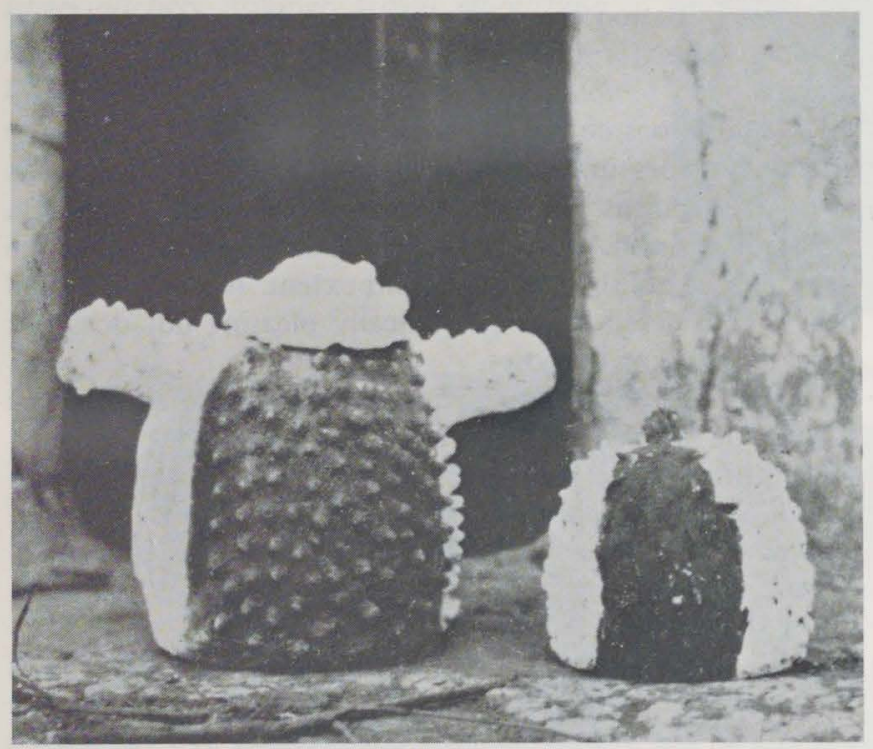

Figure 2 -Two mbusa or pottery emblems used in the chisungu: the lion (left), blown to make a roaring sound and symbolizing the courage of the husband, and helmet (right) called the Plumed Husband. This helmet is worn during the ceremony and represents chiefly deference to the husband and to female elders (Richards 1956:80, 104). extending across traditional and contemporary popular forms constantly resurfaced as a focal point of study. The potting arts, as we shall see later, are the most apparent source of continuing artistic traditions for women in the Lusaka area. Historically, the potting arts were a source of ceremonial expression and the affirmation of womanly identity. At present, they provide a means of skilled livelihood and economic mobility among urban women. The historical and present status of art by women as a sacred form and source of communal subsistence contrasts with the predominance of men in the commercial sector of popular Central African art. Men in the commercial arts were able to make a much sharper break from tradition while women build upon and are confined by it.

In this article, my interests turn to the explanations offered by the artists of the meanings and rationale behind their networks. I compare gender-linked forms of expression in terms of culturally imposed symbolic constraints and changing types of imagery that emerge in response to the reinterpretation of conventionally accepted genres and artistic techniques. I present the artists' own interpretations of these genres and contrast gender-linked limitations on artistic expression, creative individuation, and the use of specific techniques and materials in art by and about women.

\section{THE TRADITION OF POTTING AS WOMEN'S ART IN CENTRAL AFRICA}

The background of traditional art bears directly upon the work of the women potters in the contemporary urban setting. In order to understand this relationship, it is necessary to regard potting as a basic expression of womanhood, especially in initiation rites. During the chisungu or women's initiation sequence among the Bemba, a series of pottery emblems are shown to the young woman over a three-year period. These emblems represent sacred embodiments of the young woman's duty as a wife and mother. They also depict prototypical maleness as symbolized in the lion emblems (see

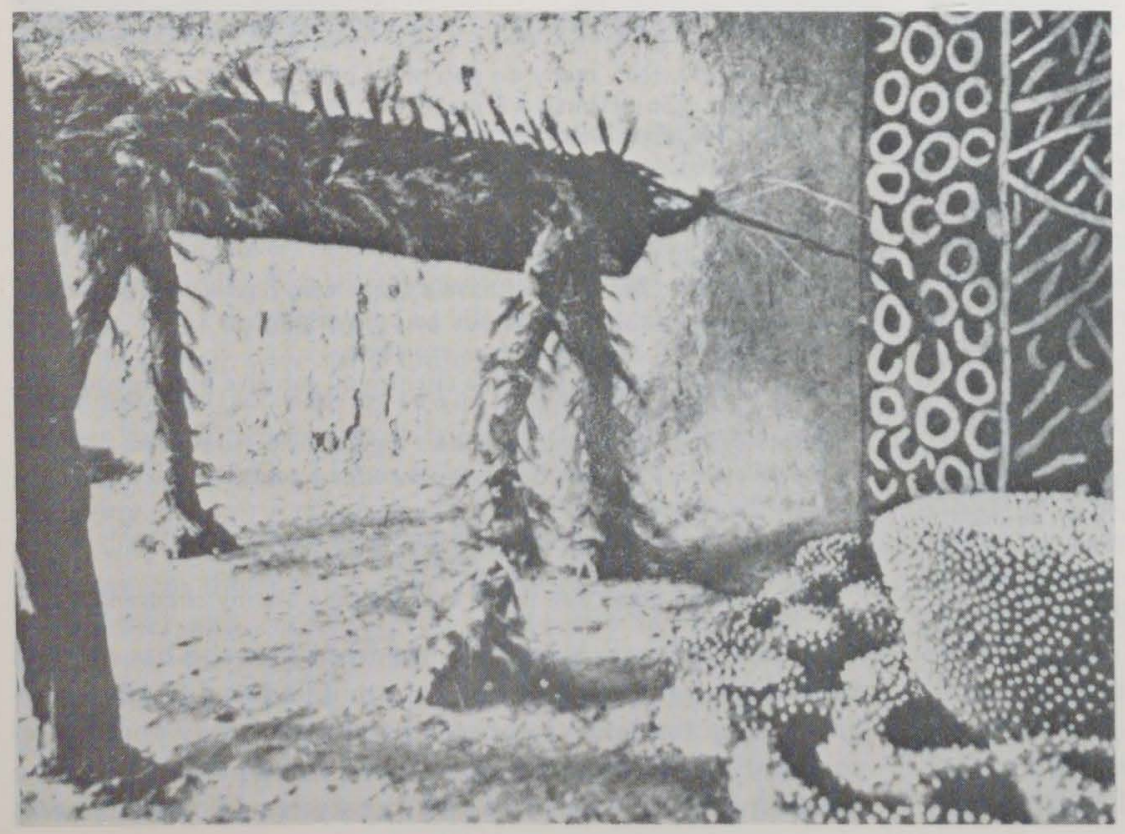

Figure 3 -Two other Bemba mbusa: a lion (left) and snake (right). The lion is used to represent the danger of the initiation ceremony as well as the husband's courage. The snake is a male symbol and warns against deceit (Richards 1956:87, 97). 
Figures 2, left; and 3, left), as juxtaposed to ideal womanly characteristics. It is important to note that in the traditional context, men may represent women directly and explicitly, while women depict men only through veiled symbolism.

The small ceramic pots (Bemba: tulongo) are important sacred symbols in the young woman's marriage (Richards 1956:31). At the time of marriage, each bride is presented a small pot by her paternal aunt. The vessel must be kept hidden and is used in a purification rite conducted by the husband and wife. ${ }^{2}$ The couple places the water-filled pot on a fire, holding it by the rim. The wife then pours water over her husband's hands and the fire, after which she relights the fire. This ceremony purifies the young couple so that they can enter their new home and light its hearth fires. It is said that this ceremony is also to be performed after each sexual act in which the couple engages. The pot, which contains purifying elements, is the woman's responsibility and ceremonially unifies the nuclear family. Audrey Richards' Bemba informants described the traditional importance of the pot to her at length (Richards 1956:30-32). My Bemba informants in town confirmed these explanations by emphasizing the traditional significance of ablutions often ignored by contemporary couples.

The mbusa or emblems of initiation are varied in form among the Bemba. They include symbols of fertility, such as the crocodile and the snake, and other animal figures intended to teach young women family responsibilities. Men are not allowed to witness the making of emblems and are mocked and verbally abused if they happen to do so by accident. Uniform ritual directives form the guidelines for making mbusa. Even experienced potters must follow a strict ritual format for art production, and they are not allowed a great deal of individuation in their work. While the lack of individuation is characteristic of traditional ceremonial artifacts, it is also preserved as a major feature of contemporary women's potting.

Among Central African groups such as the Ndembu of Zambia, distant neighbors of the Bemba (Turner 1967:151277), male initiation is similarly associated with a variety of plastic art forms, including raffia weaving and wood and raffia masking. These arts are held in strict secrecy from women, who may die if they see certain masks or witness their production. ${ }^{3}$ The sacred value of art forms and their sex-based differentiation is so extensive that it creates virtually autonomous spheres of knowledge (D'Azevedo 1973: 322-326). One ethnographer described this gender-linked barrier in art production with respect to the deference accorded to male carvers by the Gola women of West Africa when they commission special dance masks:

\footnotetext{
The carver demands that they [the women] treat him with all the respect due the creator of an object of such importance. They must humble themselves by disrobing and must utilize an elaborate language of deference. Furthermore, they must carry on all negotiations with him in secret tryst, pay an initial and final fee without fail, and provide good food and other comforts for him and his guardian spirit during the entire course of creation [D'Azevedo 1973:324].
}

The women are ritually and politically prevented from making their own wooden masks and carvings and must rely on the male intercessor in order to obtain them. The power of artistic production is placed in the hands of men. In addi- tion, creativity for men is treated as an idealized individual activity. While carvers' societies do exist in West and Central Africa, carving is regarded as an individual activity passed from one male teacher to his apprentice. It is seldom executed in cooperative groups. The act of individual creativity for carvers reinforces social hierarchy rather than equalizing it through group activity.

\section{BEMBA WOMEN CARVERS IN URBAN AREAS}

The women potters in an urban environment rarely participate in initiation ceremonies. Instead, they make the squat rounded pots for the storage and consumption of homebrewed beers (chibuku and kachiasu). These pots have standard decorations consisting of small hatch marks in cross or diamond shapes under the lip of the pot. After the pot is fired, it is burnished with a small stone, which gives it a pewter-like finish. Only one tint of burnish is used, but the pots may be polished to a different extent. A highly polished pot is considered more aesthetically pleasing but does not excel for brewing purposes.

The village techniques of pottery making are also used in town. The women collect clay and work on their pots in a social atmosphere. The homes of the Lusaka potters in Marrapodi, a shanty area four miles north of the capital, are located adjacent to each other along the banks of a small stream. From the stream, they draw both the clay and burnishing stones used in their potting.

Mrs. Kave, my main informant among the potters, was a woman in her early fifties trained as a nacimbusa or Bemba initiator in her youth. She developed potting as a marketable skill in town and maintained her ritual duties in the urban community. She stated that she and her colleagues were able to make approximately ten pots each in a two-day sitting. On the third day, they fired the pots and on the fourth, they burnished them. The pots were then ready for use in the weekend beer brewing celebrations. Beer is brewed Friday afternoon and Saturday morning for consumption in the evening. Mrs. Kave explained her production and marketing methods to me:

Interviewer: How many do you make per day?

Mrs. Kave: Sometimes we make five per day if they are small; if they are large, we make three.

Interviewer: If you make a hundred and take them to town to sell, can you sell them all in one day? Do you usually sell on credit?

Mrs. Kave: No, we just sell them here. We don't have any clients who resell them either.

Interviewer: Can you ever have a client who resells your pottery in town or in a store while you go on working?

Mrs. Kave: No, we don't have even one.

Interviewer: But if you see a client, you can give him a good price so that he can buy many?

Mrs. Kave: Yes, we can give him a good price so that he can buy.

Interviewer: Can you find a child to help you with the work or to bring you water or wood?

Mrs. Kave: Yes, there are children, there are many of them.

Interviewer: What do you pay them?

Mrs. Kave: I don't pay them, because they are my children.

In this excerpt, Mrs. Kave indicated that she has no paid employees for production and no middlemen for urban marketing. She retains a traditional pattern of family apprenticeship and engages only in face-to-face cash sale. Although the location of her home on the path between two shanty areas 
Figure 4 -Mrs. Kave, an urban Bemba potter, shapes a stem pitcher. Already finished pitchers, tulongo (small all-purpose pots), and large water pots are displayed for sale, while others await firing and burnishing.
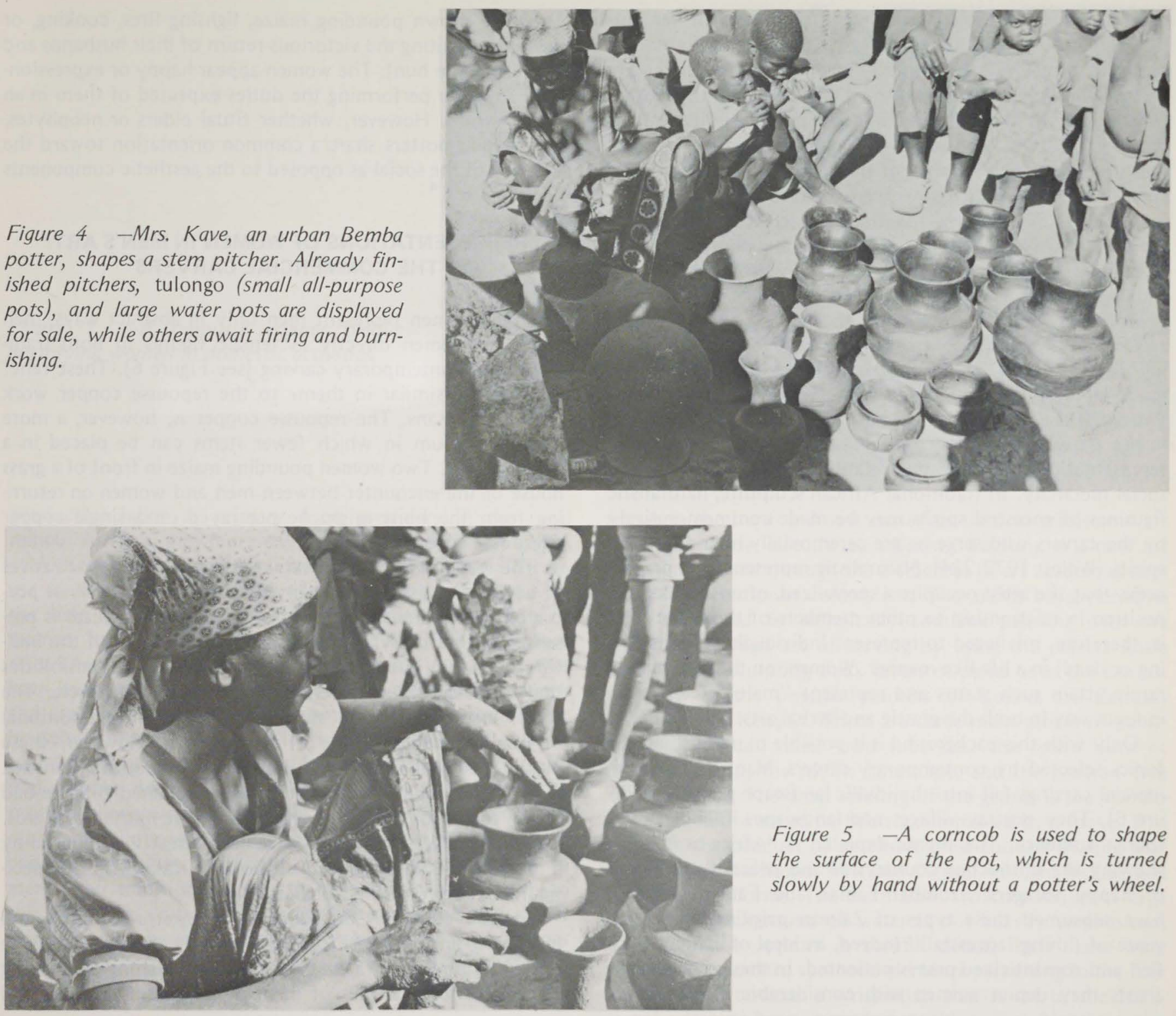

Figure $5-A$ corncob is used to shape the surface of the pot, which is turned slowly by hand without a potter's wheel.

made it possible for her to display the pots and sell them to passersby, the majority of her clients were personal acquaintances.

The beer brewers are known as shebeen queens. Historically, their activities developed during the early days of migrant labor in Central and Southern Africa, when men often left their wives and children at home to work on an extended contract basis in town. The shebeen queens are the women around whom a male friendship group centers (Mayer $1971: 298-300)$. They stand in complementarity to a recently emerging category of shebeen kings, the popular term for men who transport and distribute illicit brews of their "queens" in the shanty areas. The shebeen queens generally live alone, and receive several male clients. The outsider might see them as "prostitutes." However, they are not viewed in this way by the community and must be distinguished from "modern" prostitutes or "call girls." The shebeen queen organizes the weekly parties, and her pottery is sold along with the beer. Her work is valued only in terms of the social context in which it is used. It is both made and handled in large groups. The pots themselves are intended to be so uniform that only the keenest eye can distinguish between the marks of one woman and another. The pay received for the pots is low: about $\$ 0.50$ for the small pots and $\$ 1.00$ for the large ones. The women set their own market rates and seldom break their solidarity to increase profit.

A major distinction among the women potters is that between the traditionally and more recently trained women. Some of the potters received their training in the traditional milieu and functioned as chisungu elders, while others were trained in town by older women. The chisungu elders have a larger repertoire that includes initiation figurines. They possess a sense of artistry, working on each pot or figurine until it has, in their estimation, reached a point of perfection. These women learned their craft through years of arduous apprenticeship to elders. As a result, they practiced their art forms until an accepted standard of excellence was achieved.

Mrs. Kave is an excellent example of a nacimbusa who 
continues to view her artistry as the foundation of her potting. She takes time to teach her colleagues skills and is proud of the perfection of her works. In contrast, the young women who learned to pot in town were less aware of aesthetic conventions and utilized only a limited repertoire of standardized patterns. They had not had direct contact with the meaning or stylistic format of traditional ceramic and terra cotta work. When their pots were cracked or punctured by inept firing, they became functionally useless as well. Hence, although artistry by women is basically standardized in format and production procedure, there are differences in the training, skill, and dedication with which the women approach their art.

On several occasions, Mrs. Kave emphasized that her training differed in its extent and detail from that of her colleagues. Holding an ornamental vase in the air, she stated: "Many of them do not know how to make these." Her pride in her art was clear. The cultural reason for this difference in representation rests on the relationship between art and social hierarchy. In traditional African sculpture, naturalistic figurines of ancestral spirits may be made commemoratively by the carvers who serve or are ceremonially linked to those spirits (Willett 1972:224). Naturalistic representation presupposes that the artist occupies a specialized, often aristocratic, position in relationship to other members of the society. He is, therefore, privileged to represent individuals (whether living or dead) in a life-like manner. Women, on the other hand, rarely attain such status and represent "male forces" in an indirect way in both the plastic and verbal arts.

Only with this background is it possible to understand the topics selected by contemporary carvers. Many of the commercial carvings fall into the idyllic landscape genre (see Figure 6). They portray villages and landscapes intended for a tourist audience. The theme depicted is "Africa as it was," showing the untouched countryside and peaceful portrayals of happy villagers. Szombati-Fabian and Fabian (1976:5) have subsumed these types of Zairean paintings under the genre of "things ancestral." Indeed, an ideal of life in a glorified and romanticized past is presented. In these scenes, male artists may depict women with considerable individuation.
They are shown pounding maize, lighting fires, cooking, or passively awaiting the victorious return of their husbands and sons from the hunt. The women appear happy or expressionless. They are performing the duties expected of them in an idyllic world. However, whether ritual elders or neophytes, the women potters share a common orientation toward the primacy of the social as opposed to the aesthetic components of their work. ${ }^{4}$

\section{REPRESENTATIONS OF WOMEN IN MEN'S ART: THE COMMERCIAL CARVERS}

While women represent men only in abstract ways, men represent women directly as female figures in both traditional and contemporary carving (see Figure 6). These relief carvings are similar in theme to the repousse copper work done by artisans. The repousse copper is, however, a more limited medium in which fewer items can be placed in a single plaque. Two women pounding maize in front of a grass house or the encounter between men and women on returning from the hunt might be portrayed on a single copper frieze (see Figure 7).

The woodcarvings, however, contain continuous narratives in which the history and daily life of a single family is portrayed, or, alternatively, a set of autonomous friezes is presented with a unifying theme, such as the aging of the individuals within the family and the multiple responsibilities that one assumes at different phases in the life cycle. The artists assert that these stories are drawn from traditional myths, particularly those of Kuba origin. However, these myths are reinterpreted in a contemporary cultural context. One of the copper workers, Kabela, explained that he had drawn topics for the friezes from village life in the Kasai area. The woodcarvers claimed to have been directly influenced by a missionary school opened in the West Kasai with the specific intent of preserving Kuba art forms.

Table 1 compares the subjects and interpretations found in carving and repousse copper work. The women in these scenes assume either a passive position, watching or awaiting the successful activities of men, or engage in peaceful and

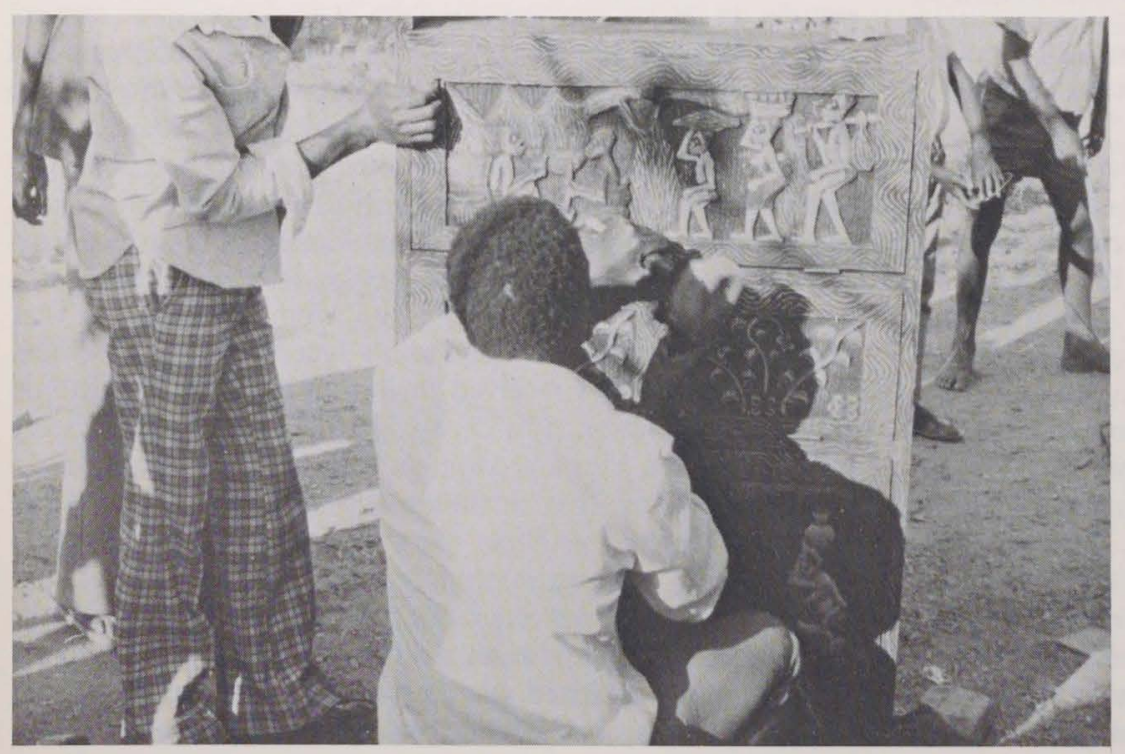

Figure 6 -Apprentice carvers highlight the figures in a domestic scene on an ornamental cabinet. Women are depicted working in the midst of the family group. 
Figure $7-A$ repousse copper plaque portraying women in domestic activities.

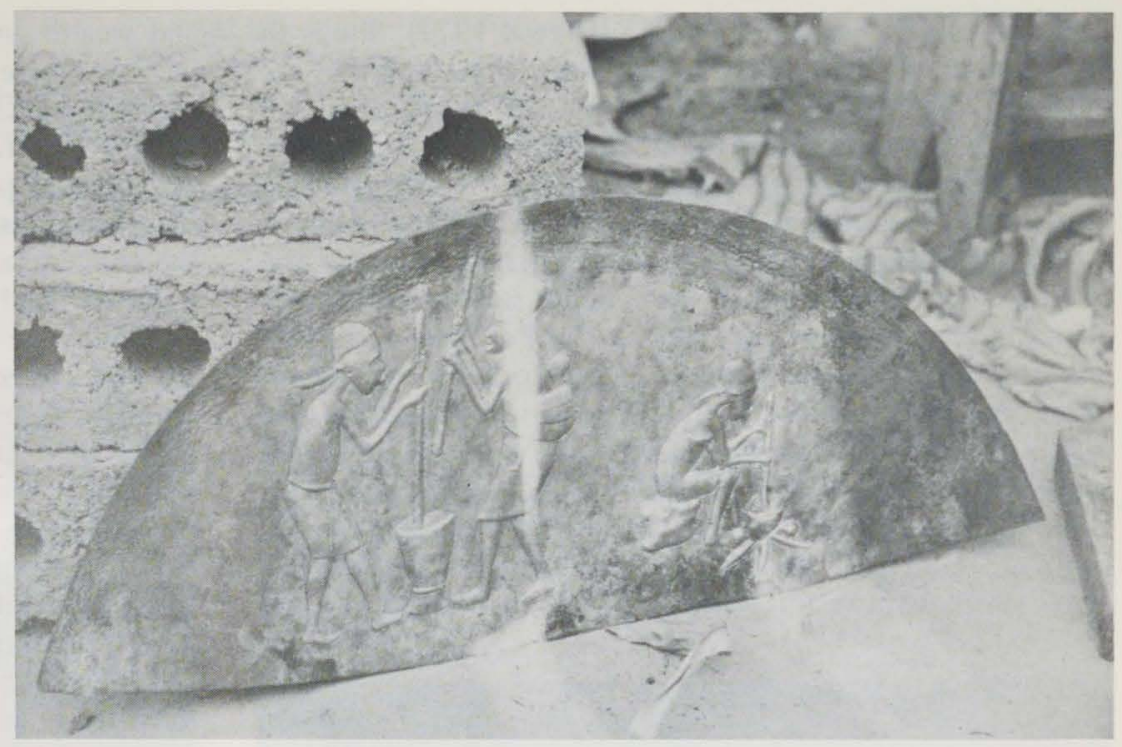

productive labor as primary food providers in the rural milieu. As such, they represent a high degree of male nostalgia.

Although the images of women portrayed in these friezes use traditional symbols, they may be better understood with the help of contemporary theories about the position of women in urban life. Hansen (1975:777-799) and other researchers have suggested that women living in shanty towns have lost some of the traditional value vested in their work and are, instead, viewed as economic noncontributors to the household. As a result, fertility rates rise in urban areas as part of the woman's attempt to redefine her identity and importance. As the sacred symbolism that surrounds the traditional woman's associations is transformed, women are represented in popular artwork as domestic figures, whose existence becomes meaningful only in their relationship to men. Their traditional productivity is shown as belonging to the past. This contemporary redefinition of the position of urban women becomes particularly evident in the paintings of "elegant" or frivolous women that will be discussed below.

\section{IMAGES OF WOMEN IN CONTEMPORARY OIL PAINTING}

Contemporary oil painting is at the opposite end of the art continuum from traditional potting. The earlier contrast between the hard and soft materials used in traditional art does not apply directly to painting. Painting is a new art form introduced through the influences of art academies supported by European colonialists. The artists have, nonetheless, attempted to technically combine painting with the traditionally high art of carving by using the palette knife and literally sculpting thick layers of paint onto the canvas.

Many of the popular painters of Lusaka are Zairean, Rwandan, or Kenyan. There are three main genres of painting that contain their own substyles: the mami wata or mambo muntu, the idyllic landscape, and the portrait (see Figures 8-20). The most striking of the genres is the mambo muntu, a half-woman, half-fish accompanied by a snake. This figure is the product of extensive cross-cultural sharing that draws upon traditional West and Central African, Indian, and European art forms. The mermaid is typically shown in large scale. The background of water is not heavily emphasized, but the figure appears in careful detail. Each mami wata repeats the standard symbolic elements pertaining to the folk belief in her powers: a wristwatch that is set to the traditional witching hour, a modern necklace that functions as a charm, and a snake, held in her hands, into which she can transform herself when seeking vengeance for betrayal.

As an image of woman, the mami wata is both voluptuous and dangerous. A popular Nigerian song invites males to approach and make use of her powers ("If you ever see mami

TABLE 1

WOMEN IN THE IDYLLIC LANDSCAPE: CARVING AND REPOUSSE COPPER

\begin{tabular}{ll}
\hline Subject Variations & Images of Women \\
\hline $\begin{array}{l}\text { Domestic scenes } \\
\begin{array}{l}\text { River scenes } \\
\text { (women watching) }\end{array}\end{array}$ & $\begin{array}{l}\text { Women cooking or preparing grains or } \\
\text { foodstuffs (passive) }\end{array}$ \\
Hunting & $\begin{array}{l}\text { Women watching men in pirogues or } \\
\text { carrying water (passive or productive) }\end{array}$ \\
& $\begin{array}{l}\text { Women watching the return of hunters } \\
\text { (passive) }\end{array}$
\end{tabular}


wata, oh, never, never run away") (Drewal 1977). She is to be exploited for her ability to produce riches. Yet, like the image of the harping wife, she is also to be placated and avoided lest ultimate ruin result. Following in the tradition of her European predecessors, the siren and the mermaid, she attracts men and thereby gains the power to destroy them.

An unmistakable cultural borrowing has occurred in the development of the mami wata figure across subSaharan Africa. Some scholars trace her to the Portuguese colonial importation of the mermaid to West Africa on ship figureheads and to contact with other Mediterranean sources during the colonization process. She has also been related to the pantheon of female snake deities in Hinduism (Drewal 1977; Dimock 1961:307-321). Above all, she unifies a broad spectrum of traditional African religious beliefs that associate water spirits with fertility and womanhood on the one hand

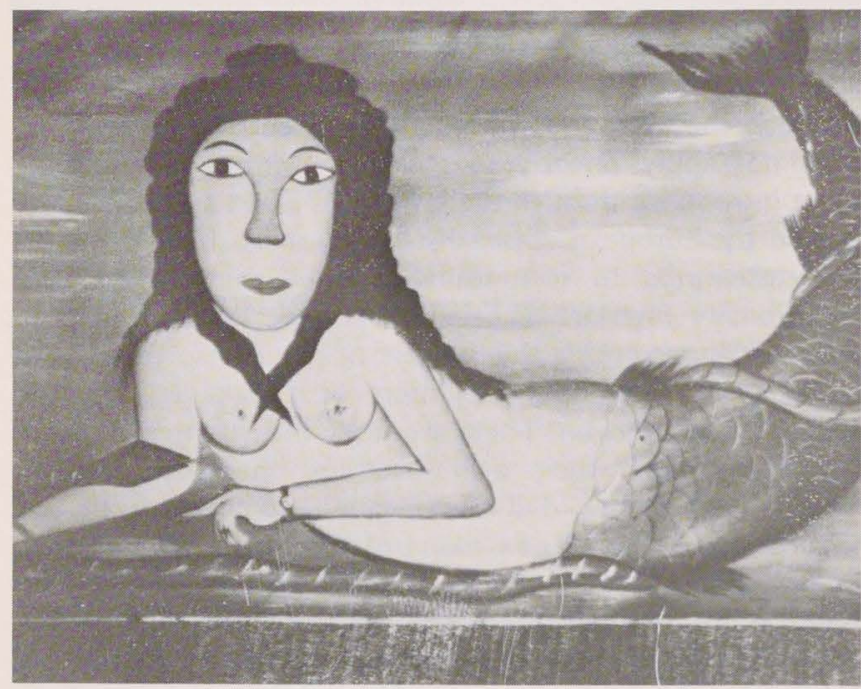

Figure 8 - The mermaid figure (mami wata or mambo muntu), symbolizing rapid wealth and power. The snake denotes punishment of those unfaithful to her. and wealth and power on the other. ${ }^{5}$ The mami wata is a mother figure employing the creative female element with counterbalancing destructive features. The mami wata expresses the traditional African segregation of gender-linked activities, already emphasized in our discussion of initiation. In addition, she retranslates this traditional avoidance into the enticement and danger that women represents in contemporary urban life.

While the idyllic landscape depicts the domesticated women, the mami wata throws the woman back to a natural or brute form. ${ }^{6}$ She is part fish or animal. She is also part anima or uncontrollable spirit. And she is, pictorially, part woman in raw flesh. The mami wata is seldom copied as a portrait of a living individual. ${ }^{7}$ Although a personalized mami wata may be painted to order, this is rare. She is, instead, a representation of individualistic appearance that represents the general principles of feminine power, creativity, and destructiveness. In this sense, the symbolism of the mami wata is not unlike the biblical figure of Eve or the contemporary Western "femme fatale."

The idyllic landscape follows the same pattern that it does in reliefs and decorative carving. A set of grass houses before which contented women await the arrival of men from the hunt is most often depicted. There are also idyllic portrayals in which unisex figures are presented. These sticklike silhouettes may be shown in the foreground of a village clearing or crossing a river in a pirogue. The helmsman is always implicitly but never unambiguously male. These figures are decorative and depersonalized. The artists emphasize the prevailing powers of nature and its magical properties by deemphasizing the presence of human beings in the setting and minimizing the appearance of their control over natural forces. As such, the idyllic landscape consoles the viewer through nostalgia and redresses the human destruction of nature associated with modernization. The landscape not only affirms the things of the past but also revitalizes the past for the present.

The artists stated that the landscape painting is attractive to a generalized tourist audience of both sexes and less to African elite buyers. Its appeal is based upon the ambiance of

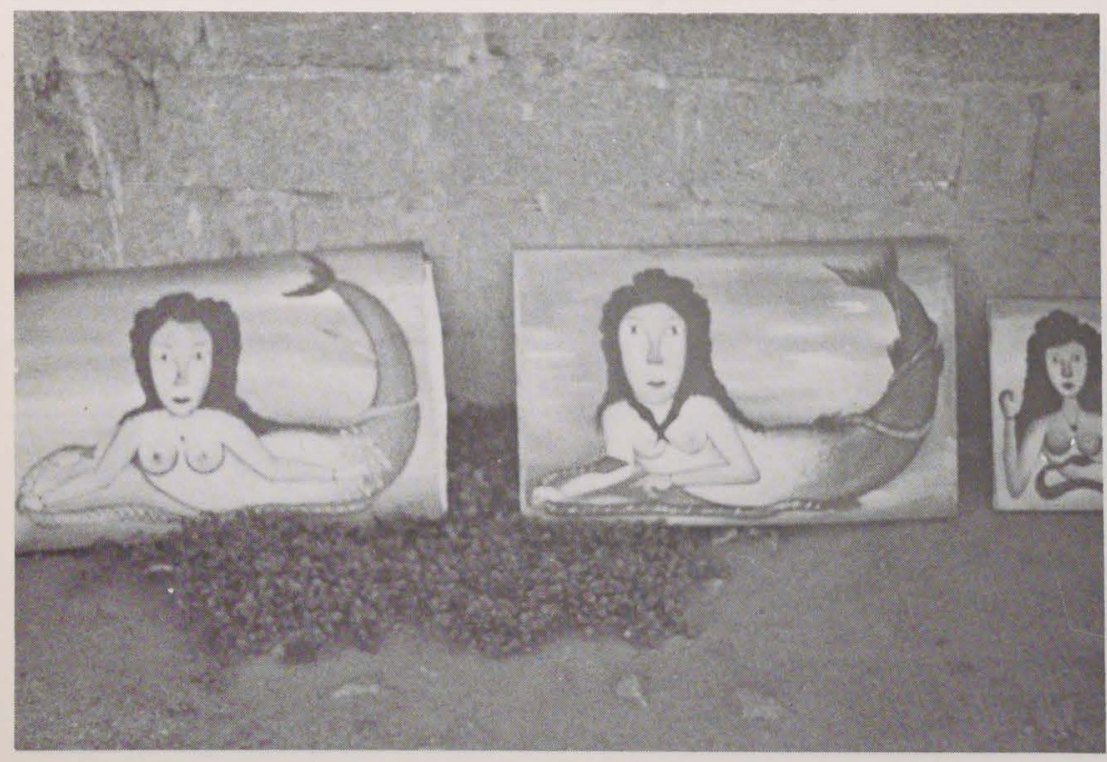

Figure 9 -Mami wata figures by the same artist, showing iconic similarities. 
TABLE 2

1. Fictive portraits

2. Actual personages
Men: old chiefs and warriors

Heads of households, heads of state, important figures, whole families
Women: young and nubile

Wives and mothers, whole families

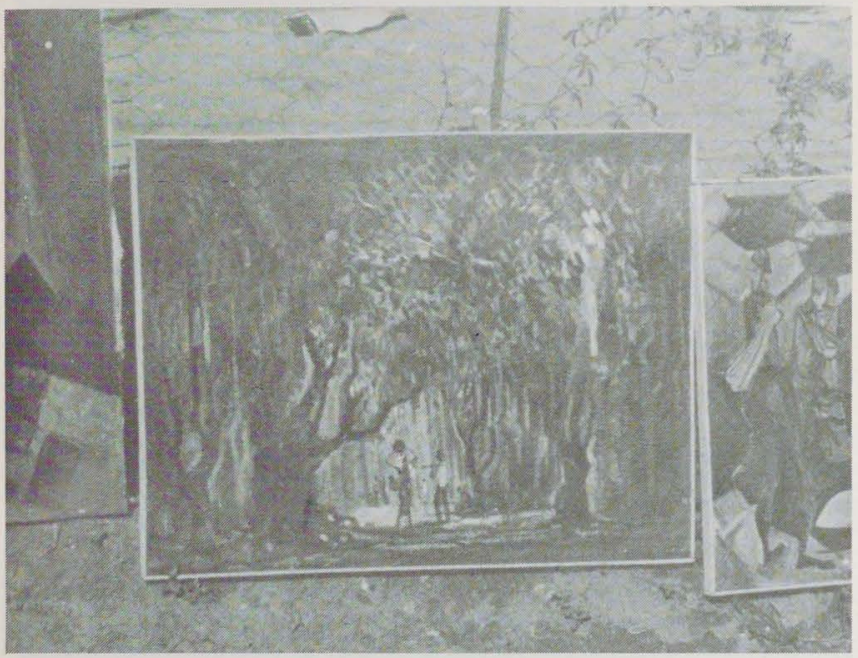

Figure $10-A$ forest scene by the Zairean lead painter, Diouf.

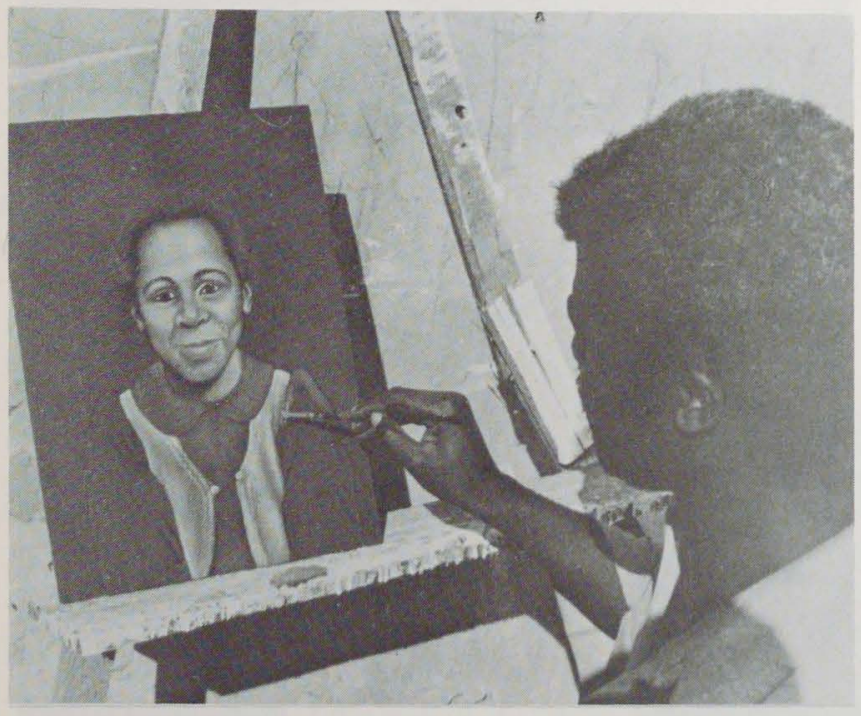

Figure 11 -Etienne fills in the velvet portrait of a tenyear-old girl, based on a photograph.

the scene, not the specific activities of the figures depicted. The figures are portrayed in a "neverland" of dreamlike ease, regardless of their activities.

Portraits contrast with both the idyllic landscape and the mambo muntu genre in terms of their lifelike characteristics and the directness with which the painter expresses his individuality. There are two major types of portraits: those of actual individuals painted from photographs and those of fictive personalities dressed in traditional garb.

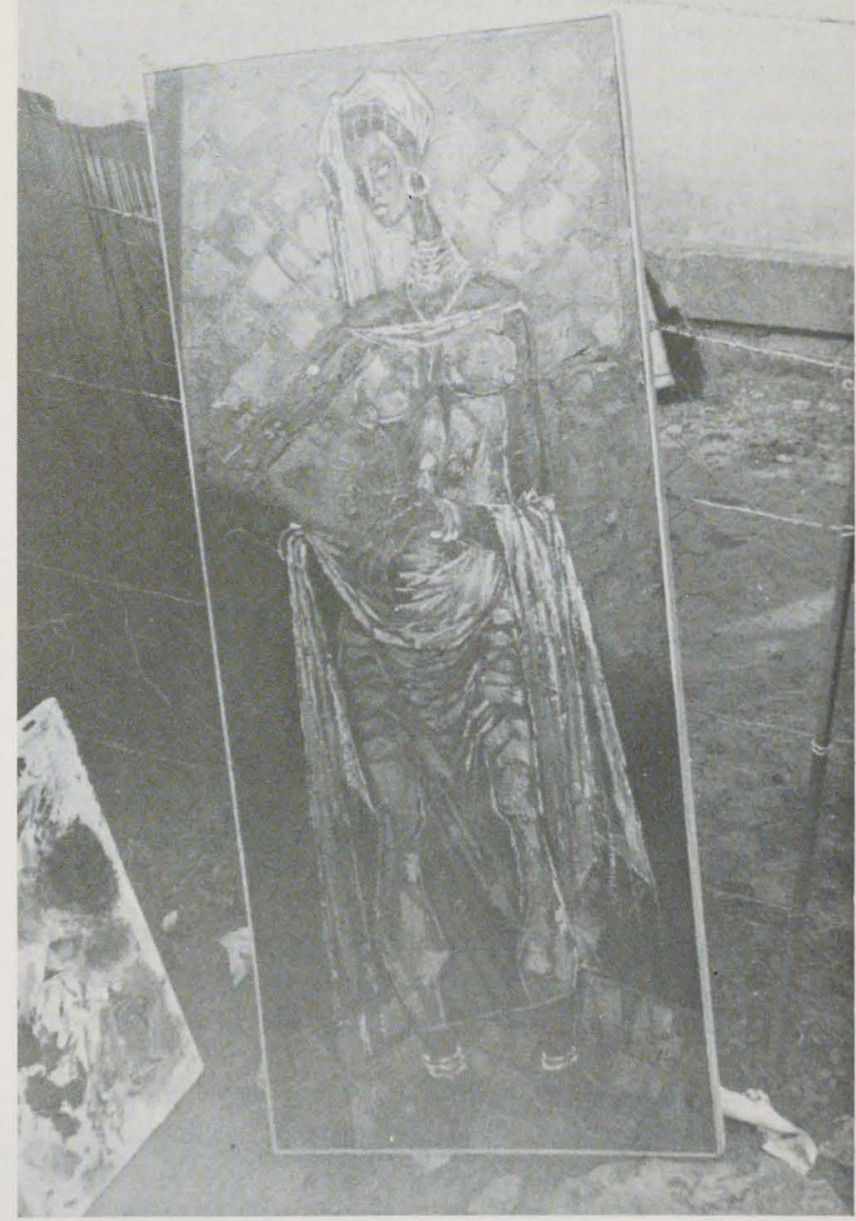

Figure 12 - "L'Elégante, " by Diouf. Note the silky materials and expensive jewels in the portrait.

The former type of portrait consists of realistic representations of individuals based on live subjects. The fictive portraits may be either veristic or abstract in execution. There are, thus, stylistic variations as well as content differences in the portrait genre. The black velvet portrait, whether of an actual or a fictive subject, employs hyperrealism as a guiding technique. Eyes glisten, skin appears vibrant, and teeth sparkle. This approach contrasts with what the Zairean painters of Lusaka refer to as figurative art moderne, that is, stylized angular drawings in which certain characteristics of an individual's appearance and body proportions have been exaggerated. The art moderne portraits are done on canvas with oil or acrylic paint. Subjects generally do not pose for such portraits. In this case, the artists consider their aesthetic goals to be experimental rather than photographic. Both the 
veristic and the more abstract styles stand in a self-conscious relationship to traditional forms of representation in carving. The photographic image is a progressive response. Traditional themes, e.g., a portrait of a village "doctor" (nganga) or a warrior, are presented as contemporary pieces. In the angular portraits, traditional conventions of proportion and contour are evoked through painting.

The velvet portrait accentuates the individuality of the client. It is painted from a snapshot, with details of clothing and jewelry added, as markers of the client's desired social and economic status. The face is highlighted from the black or blue velvet background with strong chiaroscuro that implies a direct and personal, even intimate, perspective. The figure seems to come to life and appears as if seen indoors by lamplight, a setting that conveys personal familiarity. The highlighting accents the face, emphasizing the eyes that seem to look directly at the viewer. The purpose is to lend power to the subject through enlivening the portrait itself. The portrait is not a charm or magical object that lends power to its owner as the mami wata does. Instead, the portrait is a "meditation piece" and a means of "concretizing" the imagination. In the case of photographic portraits, the depiction allows the client to project herself into an ideal economic and social setting, a painted "dream world." Two types of African women are represented alone in portraits: the elite woman and the elegant woman (also, implicitly, a frivolous woman or a prostitute).

The portrait of an "elegant woman" appears in the two figures above. In the figure on the right, the portrait is juxtaposed with the "Mother of Twins." The maternal image forms a direct contrast with the free woman. The mother with child headed for work in the fields and even the elegantly dressed mother with silks and parasol (see Figures 14 and 15) tie the more liberated woman back to her conventional role.

Diouf quickly drew the young town woman in Figure 17 while I videotaped him. In this image, he represents the ambivalent combination of her freedom, calculated elegance, and vanity.

In other black velvet portraits, women are depicted with children and are dressed in village attire or are barebreasted. These are idyllic images. Older women are seldom shown in the fictive portraits, whereas elderly male sages, warriors, and chiefs are. In a manner not unknown in the West, the man gains dignity and respect as he ages, while the woman becomes a haggard, undesirable, and often a frightening figure. Lusengu's and Kayembe's paintings below (Figures 18-20) demonstrate the differentiation between the wise old warrior and the young nubile woman ready for marriage. Note that the warrior in Figure 18 still carries his spear and shield, while the woman is more profusely adorned with traditional jewelry.

While paintings of old men and young women are common, those of older women are not. Post-menopausal women possess mystical power in Central African societies, and for this reason, it may be difficult to portray them in popular paintings without arousing considerable emotion. Female elders are respected and feared, but they are rarely if ever portrayed. During the three years that I have studied popular African art, I have not yet encountered a single figuratist painting of an old woman, although some of the more

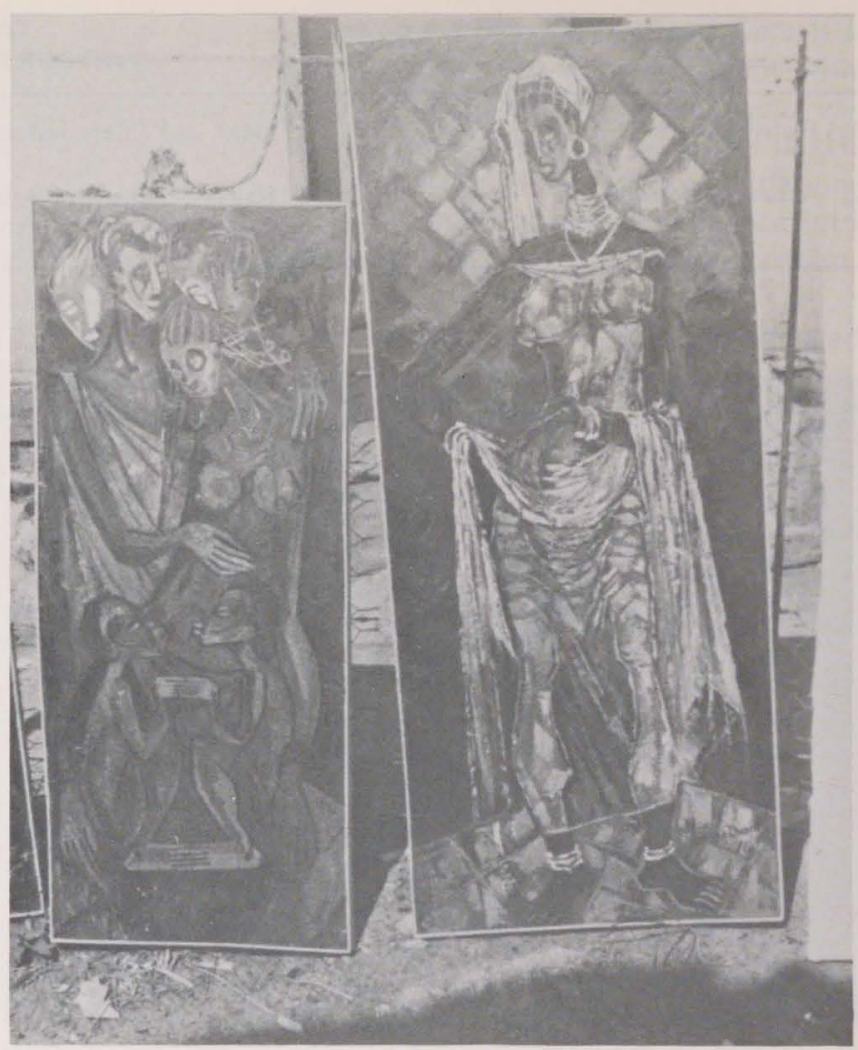

Figure 13 -Left: "The Reception of the Mother of Twins." Right: "L'Elégante."

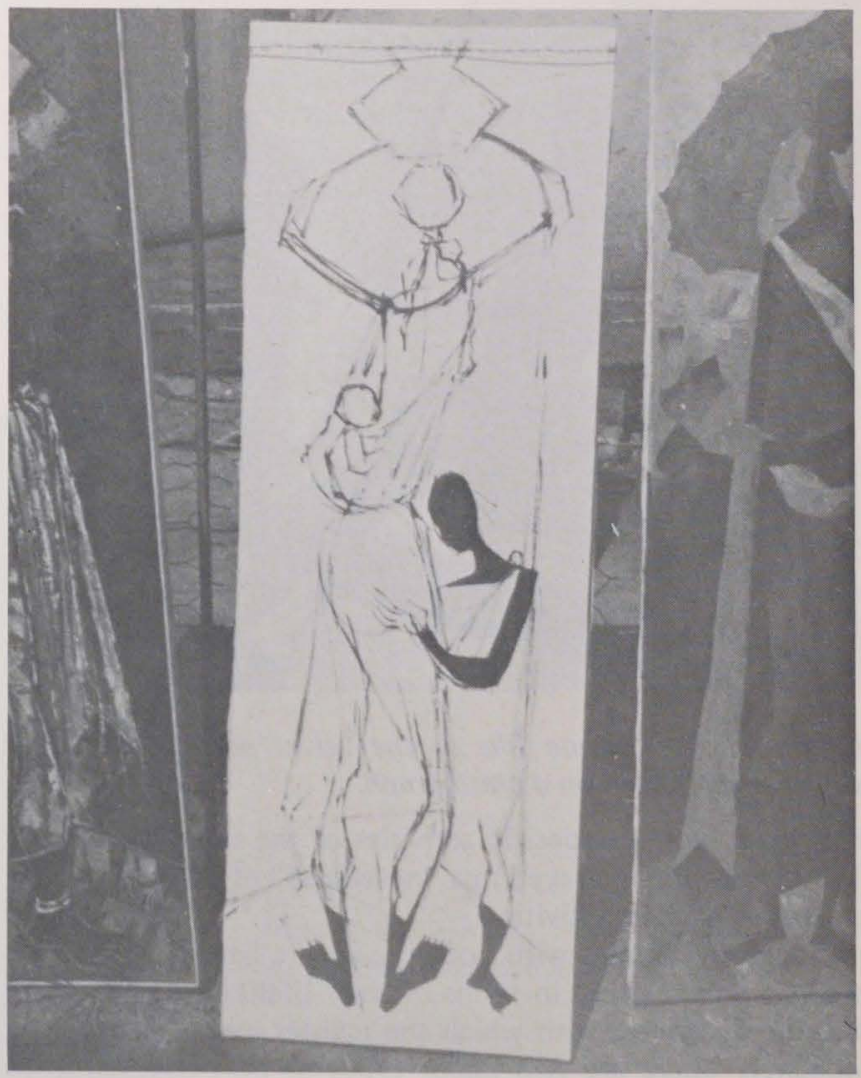

Figure 14 -Center: Untitled. Right: "Woman with Parasol and Silks, " by Diouf. 


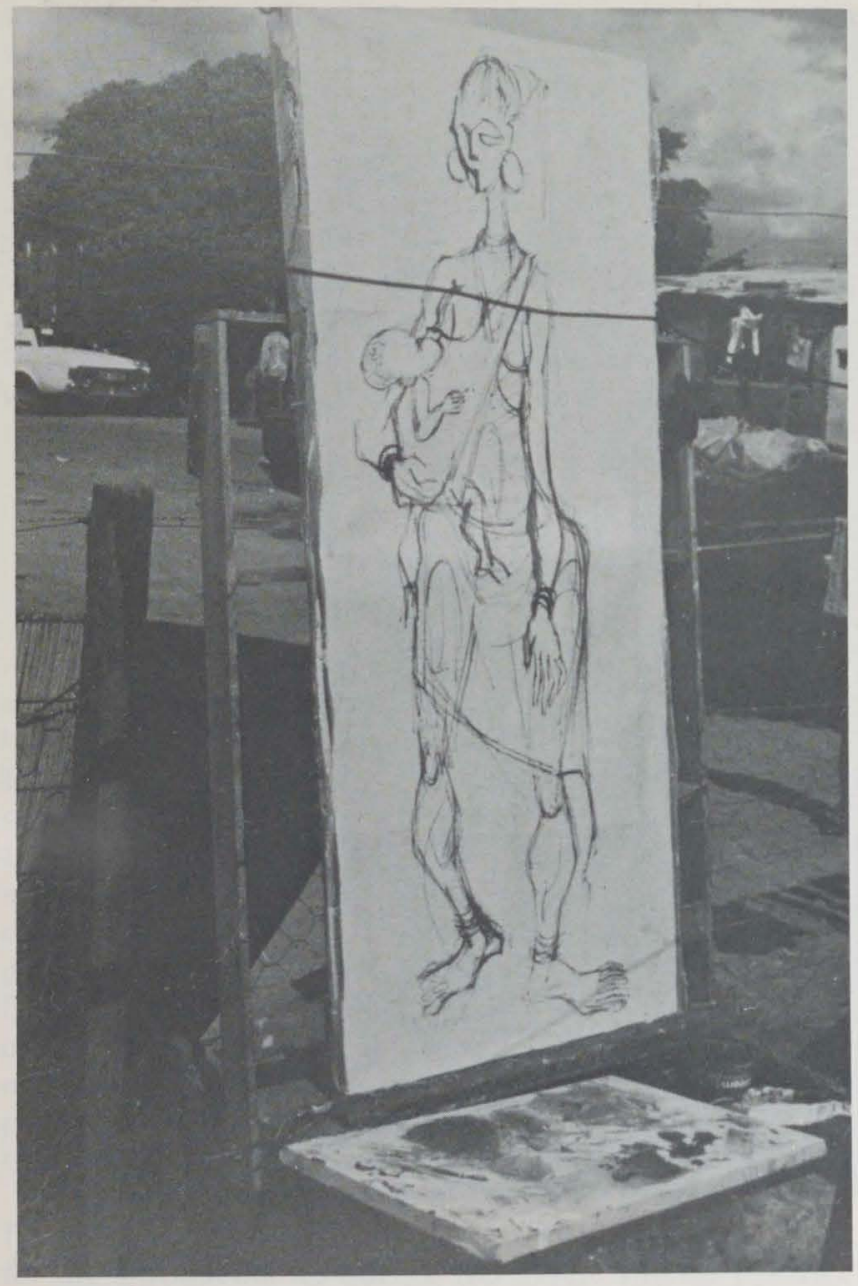

Figure $15-$ An untitled mother with child, headed for work in the fields, by Diouf.

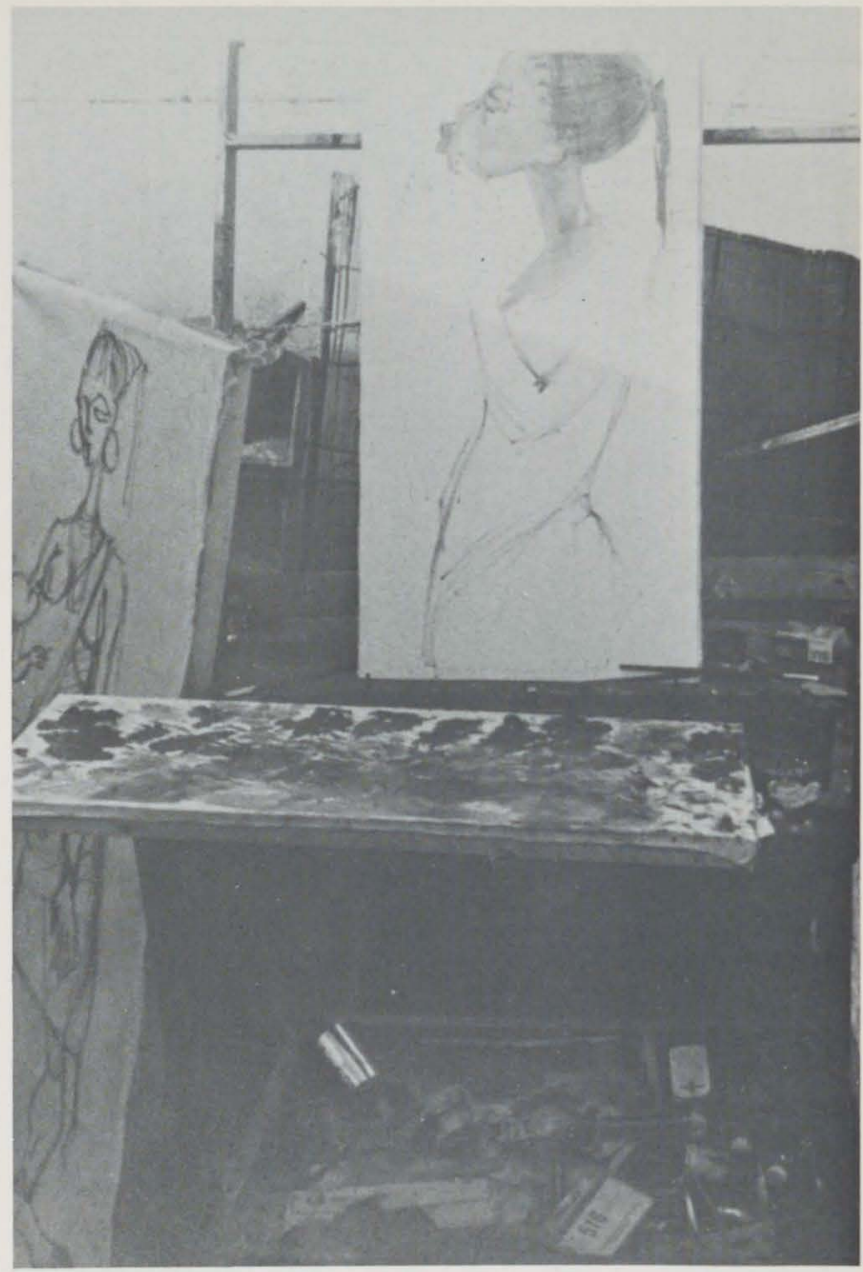

Figure 17 -Sketch of a young town woman executed rapidly by Diouf.
Figure 16 -Three of Diouf's paintings: two market scenes and "The Woman in the Field."

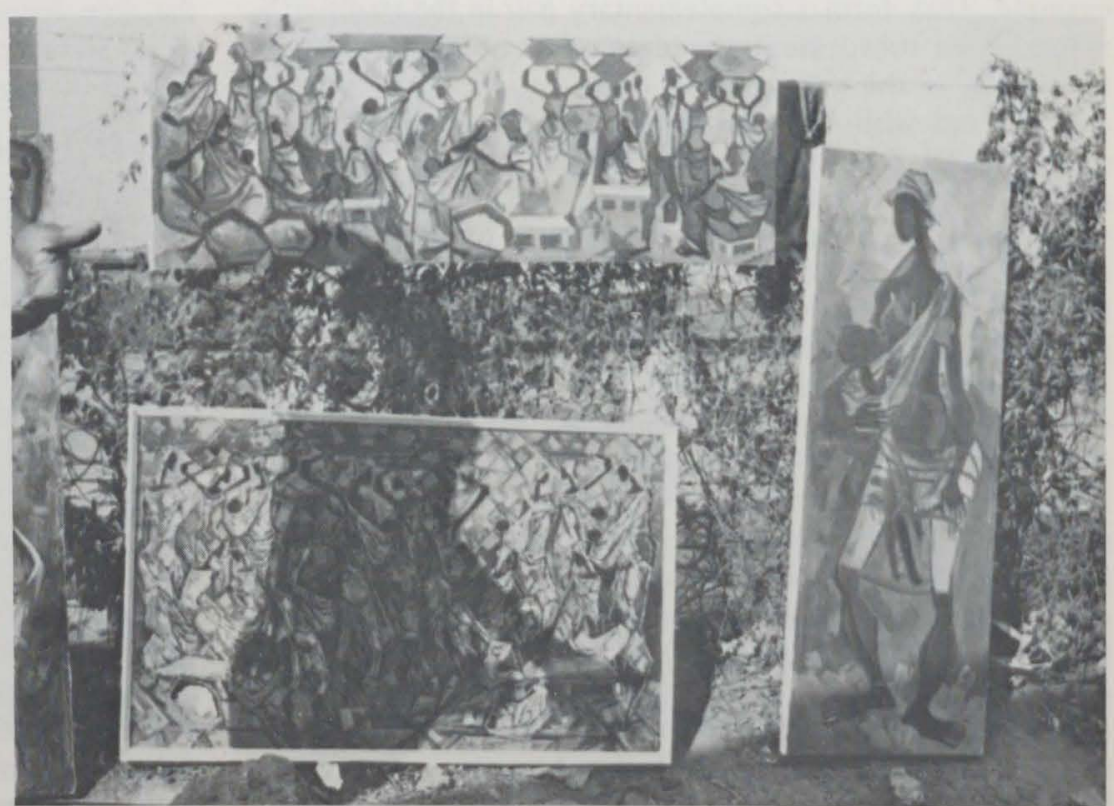




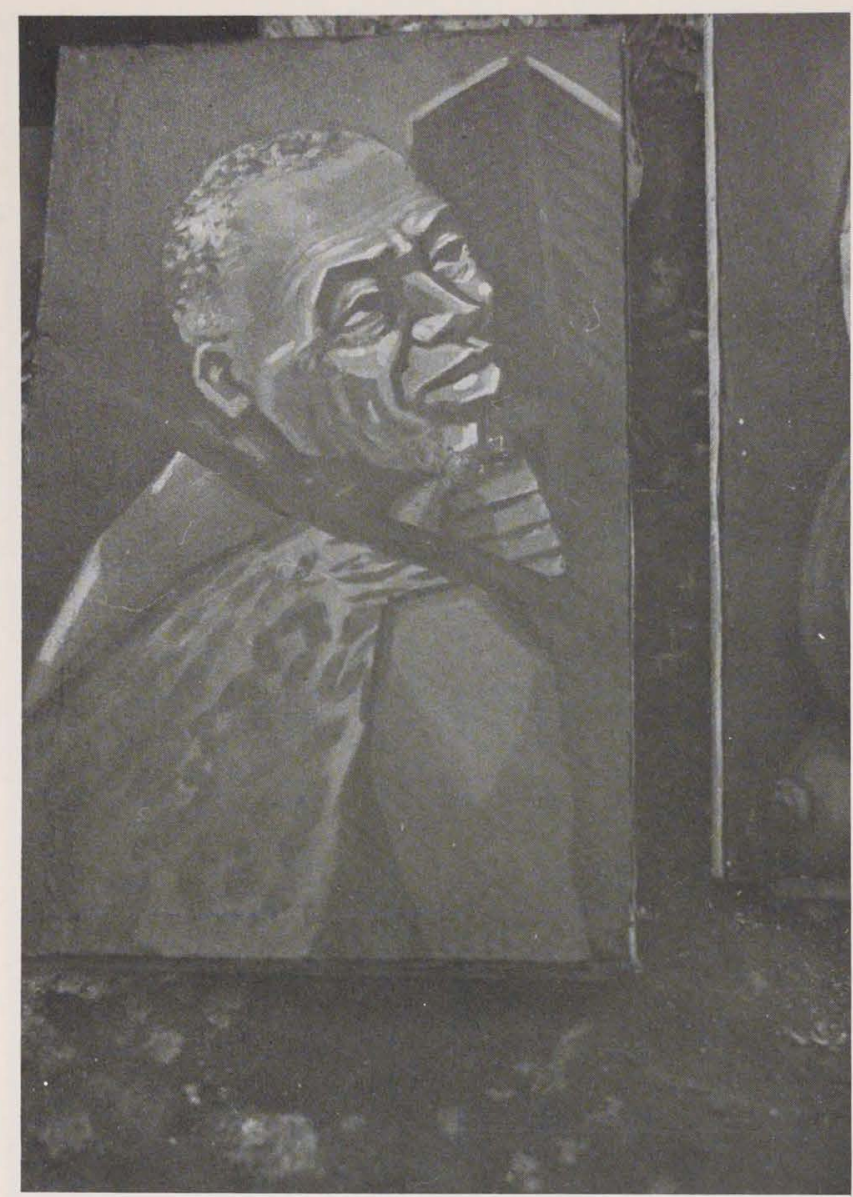

Figure 18 -Fictive portrait of an old warrior, by Lusengu.

abstract painting has been interpreted as representing older women.

By contrast, the old man/young woman form a culturally synthetic unit. They are considered eligible to marry, for example. They form a complementary pair in the traditional milieu. Their substitute in the black velvet portraits of actual individuals is the monogamous couple. Upper-class women are depicted with their husbands at some significant milestones in their lives, for example, at their marriage ceremony or when they completed European schooling. The elite woman may also be portrayed at the birth of her first child, with the mother seated, holding the child in the foreground. Mother/child is also treated as a complementary unit in the fictive and traditionalistic portraits.

Portraits of women made explicitly for sale to Europeans often present the nubile, barebreasted, frequently smiling image (see Figures 19-21). These portrayals, unlike the Latin American black velvets, are meant to be more sensuous and sensationalistic than erotic. A mother and child or a barebreasted girl in initiation headdress are highly characteristic of the fictive portraits. Figure 19, a charcoal drawing made by Lusengu from an old photograph, sold very well at his exposition. He was obliged to make several copies and expressed interest in learning to make prints in order to service a larger clientele with a single drawing.

In the fictive portraits, the artist generally focuses drama-

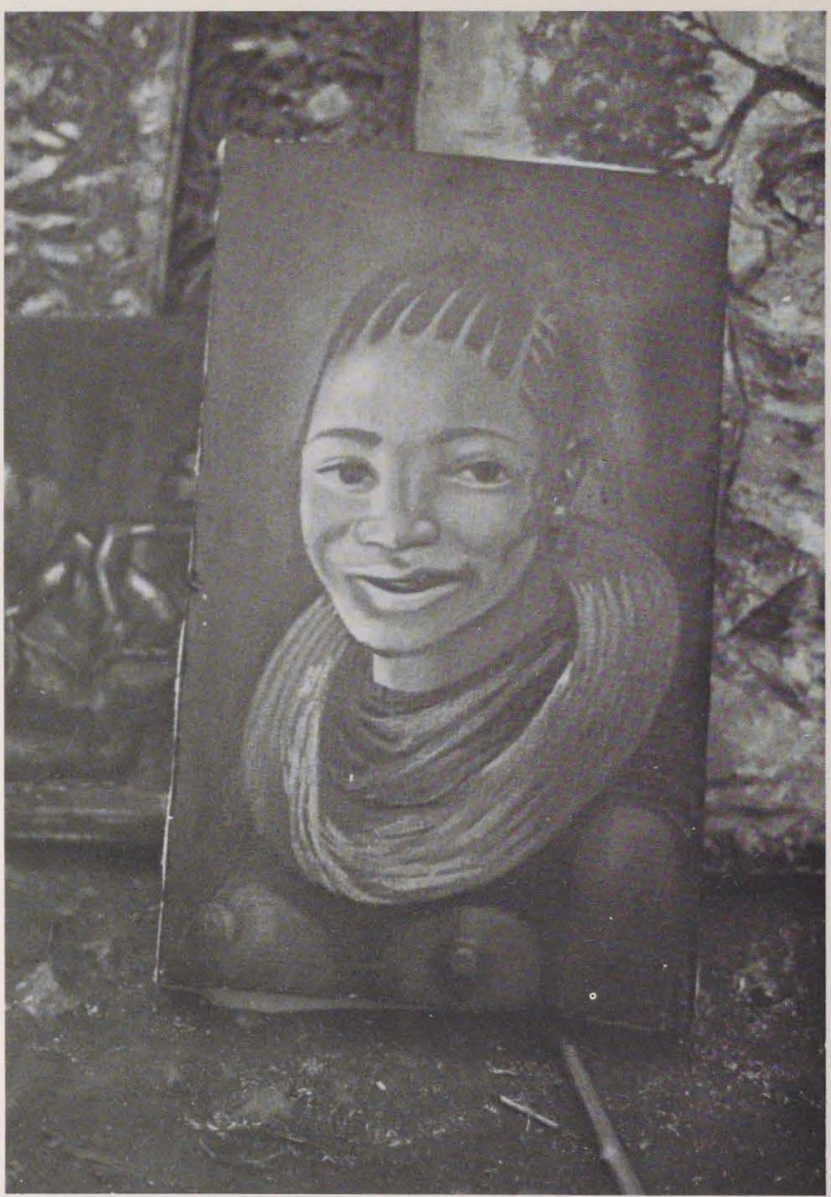

Figure 19 -Fictive portrait of a young woman, by Lusengu.

tically on one or two subjects, even showing tears in their eyes for maximum emotional impact. For background, there is, at most, a stylized surface of leaves, or voluptuous curtains. The individual subject, whether real or imaginary, is the sole focus of attention. One artist of the black velvet genre stated that his goal was to make the painting "more beautiful" than life through its vibrant presentation.

Such richness of realistic detail is confined to the velvet portrait genre alone. Kavolis (1967:76-91) links this style to a proletarian clientele and claims that it arises with urban industrial society. However, it is important to note that the very same male artists may paint in a contrasting genre intended for a different target audience.

In the art moderne paintings, realism is replaced by the elongation of features and angular contours. This is a form of revitalism in art. Traditional notions of aesthetics are evoked within these art forms. Several of the painters mentioned Picasso's art as an inspiration, both for changes in representation and for universalizing personal experience through art. The fact that Picasso drew ideas both from traditional African sculpture and from his own Iberian traditions, though not explicitly mentioned by the painters, adds an overtone to this revitalization process. ${ }^{8}$ The individuation of the black velvet realism is replaced by a modified form of representation, stressing the qualities of form and movement. This 
sense of motion enhances the themes that the modern artists wish to portray.

One of the major images, as illustrated above, is found in the modern paintings of the African peasant woman (see Figure 16, right). She is physically strong, carrying her baby and her work tools. The arm and leg muscles are exaggerated, and the head is small. The overall effect is an abstracted version of "socialist realism," elevating the hard work of the woman in the traditional milieu. Like many of the women in the black velvet portraits, the women are portrayed on canvas as mothers and epitomize the creative aspects of traditional concepts of womanhood.

\section{AN INTRODUCTION TO THE ARTIST INFORMANTS AND THEIR IMAGES OF WOMEN}

Diouf Moussa is a Zairean painter who was trained at the Academy of Fine Arts in Lubumbashi, Zaire. Among the artists whose studios are based in Lusaka's shanty areas, he has been exposed to an unusually high level of formal education. He became a professor of fine arts in Kinshasa and subsequent to that, he worked as a graphic artist for UNESCO. He had been sent by the Zairean government to do several expositions abroad in Rome, Paris, and Canada. His collection of personal art was extensive, including over 80 paintings. On several occasions when I interviewed him, Diouf was preparing for expositions. These paintings included several angular portraits of women and of settings like the marketplace in which women predominate. There were also portraits of raw peasant figures who stand in contrast with the elegant town women.

Gradually, Diouf has established himself as the central figure in the circle of Lusaka painters. The others look to him for the introduction of outside techniques and the transmission and interpretation of conventional, more Western notions of art. The statements of Diouf and his colleagues below, therefore, contain an exceptional self-consciousness and an attempt to fit themselves to an international frame-

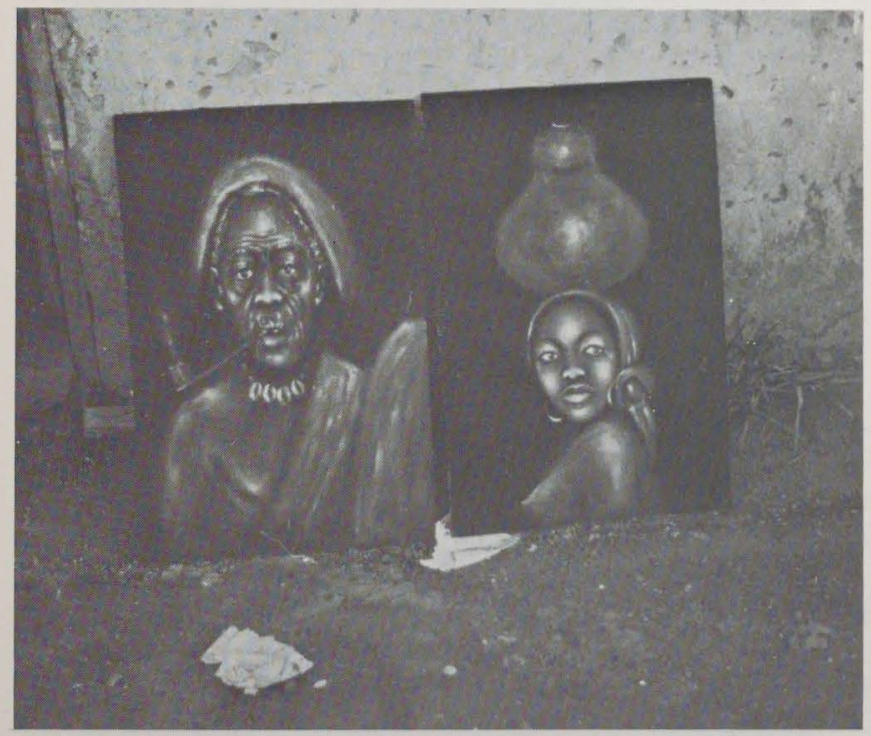

Figure 20 -Fictive portraits of an old warrior and a young woman, by Kayembe. work of contemporary art. Diouf contrasted his portrait entitled "Woman in the Field" (Figure 16, right) with another called "L'Elégante" (Figures 12 and 13, right). L'Elégante is dressed in diaphanous evening wear and carries a parasol. In another portrait, an elegant woman is depicted preparing for an evening soiree. She is barebreasted and is combing her hair. While the peasant woman labors, l'élégante has been transformed by urban life into a frivolous symbol of feminine beauty. She is to be appreciated and worshipped by men, but her contribution to the sustaining of daily life is small.

In the portraits of /'élégante, stylistic distortion and elongation are used to denote self-assurance, subtle arrogance, and grace. Another painter, Mutwale, also depicts freedom from the traditional way of life through this genre. He has manipulated certain painting conventions and ideals to create an air of mystery. The arms of his élégante are long and wiry (see Figure 22), conveying freedom of movement. Her face is merely a rude sketch. She appears as a generalized figure, not as an individual portrait. Her body is elongated and in a moving balance, with trunk angling left from the upright thighs, arms and head compensating to the right, both knees bent. Her feet are long and firmly planted. Her stance resembles the ideal of split-trunk body movement that appears in Central African dance and sculpture. However, unlike traditional sculpture, which is angled forward and back but remains upright, not leaning to left and right, Mutwale's figure angles along both axes, suggesting both movement and rest simultaneously. His élégante is both active in urban life and a fragile figure possessing merely ornamental properties.

Santos is an older portrait and landscape painter located in Chawama, a shanty area some distance from the new figuratist circle in Kanyama. He makes portraits of women that might be referred to as "primitive," using traditional canons of portraiture that seem to be drawn from mask carving. His relative, Christophe, who works primarily in the idyllic landscape genre (Jules-Rosette 1977), also paints portraits in this masklike style, which was not seen elsewhere among the

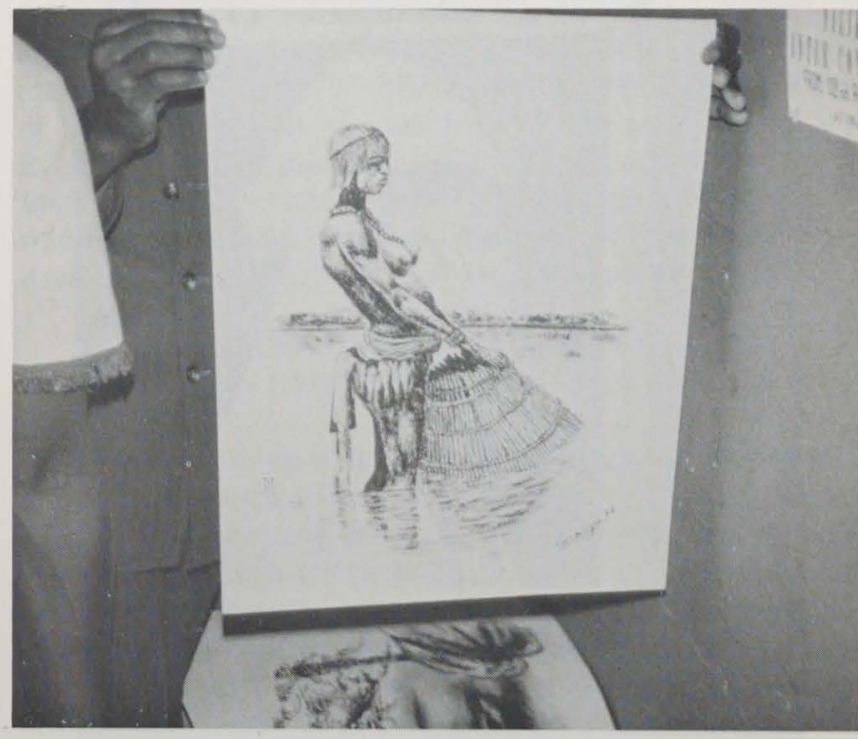

Figure 21 -Charcoal drawing of a woman fishing, by Lusengu. 


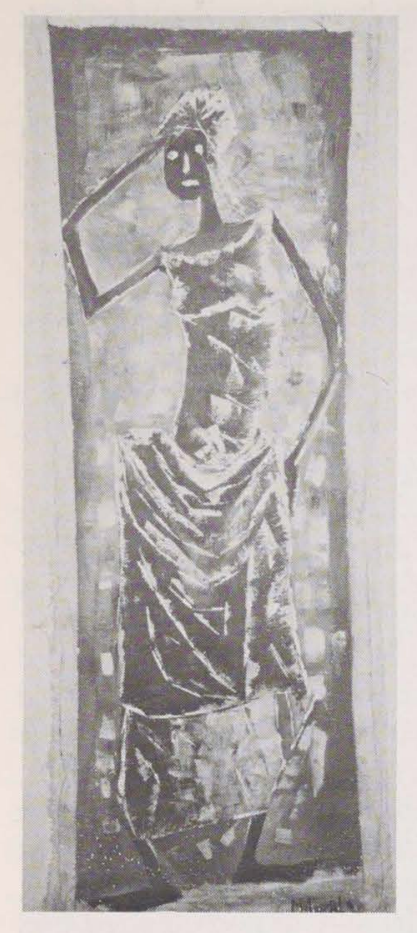

Figure 22

- Portrait

of $a$

young

woman,

by

Mutwale.

Lusaka artists. An older brother, now deceased, is said to have worked in the same style. Santos explained that Figure 24 was a portrait of Miriam Makeba. As such, both it and the Catholic "sister" portrayed in Figure 23 fit into the category of the African elegant or urban woman, but the imputation of frivolity is removed. Santos' style, transmitted through a single family, is unique.

Western and indigenous interpretations of womanhood are combined at times, in the portraits as they are in the mami wata paintings. Lusengu, another member of the art moderne

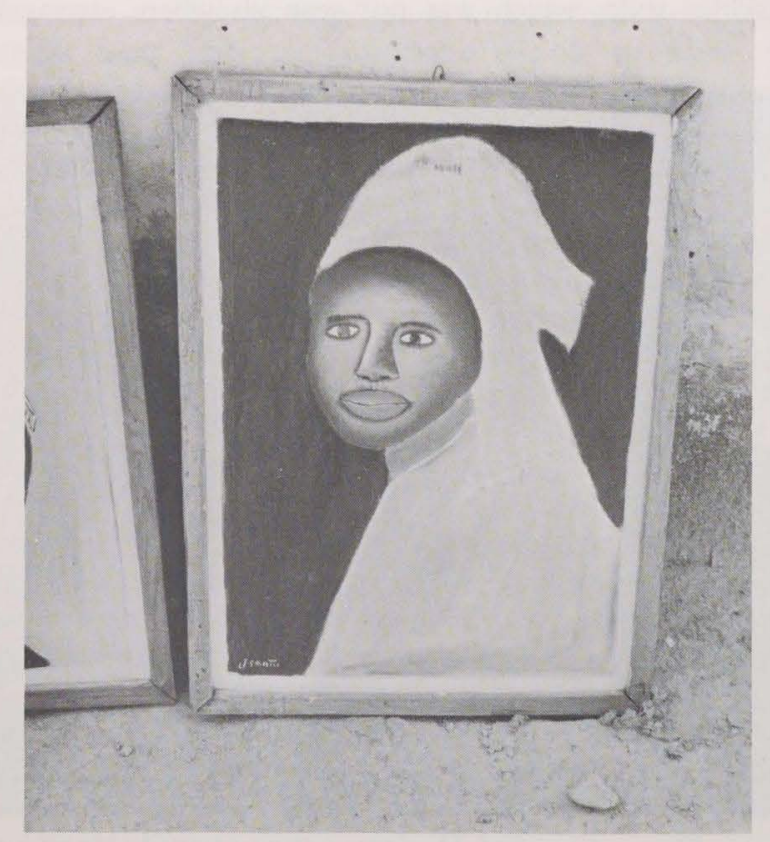

Figure 23 -Portrait of a Catholic nun, by Santos. school, made several nude portraits of l'élégante in a figuratist style. He had two years of academy training in Lubumbashi and had been in Lusaka for only six months at the time of the interview. Between 1976 and 1977, Lusengu put on two expositions at a major urban hotel, one using the moderate abstraction that he described as the "new figuratism" and the other in pastels. His audience gradually broadened to include a varied expatriate and an African elite group. Much of Lusengu's work consists of images of women as mothers, companions, and elegant models. He attempts to apply the more Western convention of the nude to the new African figuratism that he developed. The results are often baffling to both the African and expatriate customers that he tries to reach.

One of Lusengu's compositions consists of four nude women reclining. These nudes are painted in the contemporary style that Lusengu refers to as examples of figuratism (see Figure 25). ${ }^{9}$ The abstract manner of painting combined with the nude convention confused many African proletarian customers. The following exchange developed between one field informant, who was an art buyer, and Lusengu:

Interviewer: And what does this represent?

Lusengu: There-

Interviewer: It's a woman.

Lusengu: Yes, a nude woman, that represents nude women, in a style of figuratism and of modern art.

Middleman: She is about to give birth?

Lusengu: Excuse me?

Middleman: She is about to give birth?

Lusengu: Ha. Well, that's not the story, you see. Because if she was about to give birth, for a woman about to give birth never holds herself in that position. That is, there must be a matter of rest, finally repose, something in that sense, or maybe-and again, above all, it's not to give birth.

Lusengu was both puzzled and embarrassed at the middleman's request for information about what he had come to take as an artistic convention. He fully understood the rela-

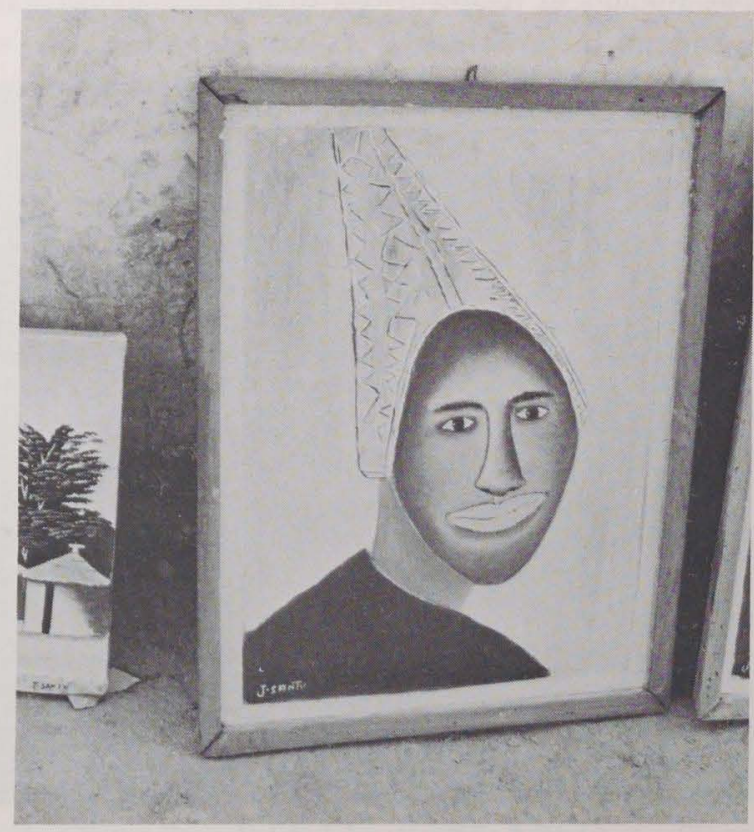

Figure 24 -Portrait of Miriam Makeba, by Santos. 


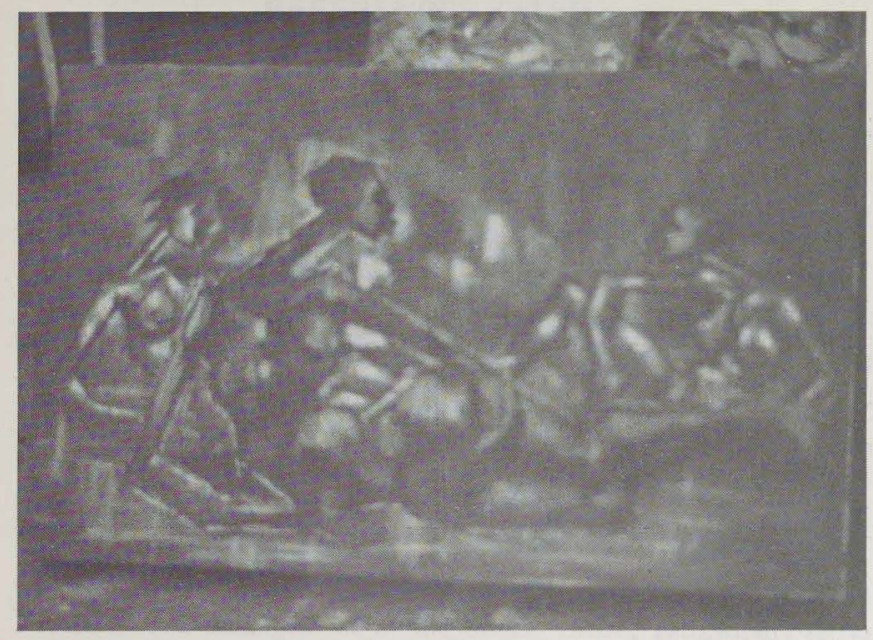

Figure 25 -Reclining nudes, by Lusengu.

tionship between /'élégante and a Western ideal of femininity. Implicitly, he was critical of this ideal. He accepted, however, its stylistic conventions as constituting an acceptable artistic code and an inspiration for his painting.

Similarly for Diouf, who has introduced the ideal of the elegant woman into the circle of Lusaka painters, this figure portrays women in an allegedly universal manner. For these painters, universality means that the content of the paintings can be equally understood and accepted by persons from diverse cultural backgrounds. Therefore, the image of womanhood portrayed is intended to touch upon some transcultural aspects of creativity, beauty, and ornamentation. Diouf explains his ideals with considerable sophistication:

Painting should not be limited to a closed audience. Painting
should be broad, painting should be human, painting should be
international. The problem isn't one of the vision of the country-
side of Kenya, or the vision of here. For example, Picasso. I cite
someone who is well known and who has achieved a great deal. He
painted Guernica, which is in a certain way, a manifestation that
he wanted to constitute for all the atrocities of war. But the prob-
lem of war isn't a Spanish problem or a Zairean problem, or a
problem-I don't know, of Australia or Europe. It's an inter-
national problem, that involves all humanity. And I think that
painting should change more and more toward such a vision of
things, that it should become universal, that it won't limit itself to
a purely local audience.

For example, the ceremony of the mother of twins here. That ceremony comes from an African milieu, very precisely; it's that which has pushed me to realize it. It's a Zairean milieu, a given tribe, but the one who says a cultural problem says a universal problem because culture is universal. Even though we come from such-and-such a milieu, it comes to be universal [Jules-Rosette 1977].

Thus, despite his emphasis on universality, Diouf often draws women in specifically traditional contexts engaged in culturally conventional behaviors. The painting referred to here, "The Reception of the Mother of Twins" (see Figure 13, left), shows a traditional twinship ceremony from Zaire. Diouf remarked that only a few of those who viewed the painting would actually have the knowledge to understand it completely. Through these highly stylized and delimited means, he hopes to convey universal feelings about motherhood and fertility. In order to evoke these feelings, he has opted in many cases for a traditional "timeless" view of women. Few of the painters depict women individualistically in specifically modern contexts. New conventions of abstraction are paradoxically used to reinforce and express on canvas existing cultural and aesthetic ideals that are applied to the social and cultural place of women. Diouf's work here foreshadows that of his colleagues, who idealize their images of women as mothers, wives, and symbols of sensuality and beauty, just as both he and the traditional Central African carvers that were discussed above have already done.

\section{INDIVIDUATION IN ART: A MIRROR OF SOCIETY}

Earlier, it was noted that pottery is characterized by a lack of individuation. Artists are encouraged to make their pieces blend with those of every other woman who worked with clay. This is less the case for the carvers. While the oil painters are engaged in a learning process during which they copy each other, their emphasis is on the uniqueness of each art work. In particular, their portraiture of women is individualistic, demonstrating both stylistic innovativeness and the distinctiveness of the subjects that they paint. However, this individuation occurs within the context of specific artistic genres. The black velvet portraits share similar contours and conventions of color and texture that contribute to their veristic qualities. The "modern" portraits are less distinctive in terms of the subjects painted. Yet, in each case, a particular woman can be recognized. ${ }^{10}$

Both male and female figures are represented in uniform and nonindividuated ways in women's pottery. In carving and painting, individuation increase. This growth of individuation is accompanied by more pride in artistry and training. Both the traditional and the contemporary carvers consider themselves as privileged and influential members of the community. The contemporary painters of Lusaka intentionally cultivate an image of themselves, by virtue of training, workshops, and marketing, as a cultural and intellectual elite. They distinguish their work from conventional art forms and attempt to create a social status that sets them apart from their shantytown neighbors. The women artists, conversely, do not develop themselves as an autonomous community marked off by virtue of their creative work. Their art is part of larger community process from it emerges as secondary. By being socially pressured to assume a particular image in the community as a result of the waning importance of their traditional positions, the Bemba women potters have not yet developed a sense of collective identity as urban artists.

\section{THE PROSPECTS OF WOMEN IN CENTRAL AFRICAN ART}

As women's only major art form, the potting arts, though offering them financial independence, do not provide women with a corresponding means of full aesthetic and personal expression through which the qualities of their lives may be explored. Thus, their limited financial autonomy is not always accompanied by a broad-based set of cultural transformations that would allow women as artists to define their positions in a transitional society.

Carving is solely a male activity and, as stated, depicts women in "safe" traditional attitudes. Its treatment of men, 
while equally static, shows more variety in image and social status. The all-male carving studios offer women no scope for participation. Painting, the most active of the Central African arts, and the one showing the most variety in views of women, nonetheless does not hold forth much immediate prospect for their participation. As yet, there are, to my knowledge, no women painters in the Lusaka artists' circle, and all the young apprentices currently undergoing training are boys. The painters profess not to know why women do not paint. One reason may be found in their background in Zairean primary schools, where European teachers steered young women away from acquiring intellectual and artistic skills in favor of domestic proficiency, once again linking the artistic inhibitions of the West and Africa. The failure to encourage women falls more exclusively on colonial attitudes than on the painters themselves, for the pattern of autonomous self-employment for women is well-established in agriculture and small trades.

Although women are topically important and are given an "authentic" perspective in the newer painting genres, no attempt is made to portray them as other than passive victims of culture change (viz., the frivolous woman). Despite their sympathy and awareness of cultural nuance, many of the painters are unwilling to express the hopes and frustrations of women. In Diouf's words, "Who says a cultural problem, says a universal problem." In their leap to the universal, they substitute a new ideal for women, less rigid and more reflective than the old, but still far from showing contemporary women in actual situations. Unless a way is found for women to participate in artistic professions, this pattern is likely to continue.

\section{CONCLUSIONS: ART AS A REFLECTION OF WOMEN'S STATUS IN SOCIETY}

Each of the artistic genres portrays women in a different social persona. The Bemba initiation figures stress the active role of women as wives and mothers. The women of the carvings and idyllic landscapes are diligent, peaceful, and domestically oriented, the male ideal of the rural wife. The mami wata, adventurous and exotic, reflects male ambivalence toward urban women. The black velvet portraits subject men and women alike to the flattering mirror of hyperrealism, but the fictive portraits turn this mirror toward traditionalistic appeal. Even the modern figures, sensitive to movement and to existing sources of vitality, remain empathetic rather than conveying the full experience of women, and for that matter, of men, in complex urban life.

The contemporary artists of Lusaka are still in the process of defining an audience. They orient toward both nonAfrican tourists and Africans of certain social classes. The work of the painters, in particular, is influenced by this ambivalence in determining its target group. As a result, the strains that both women and men experience in redefining their cultural positions are not expressed. The fact that art by women has difficulty attaining recognition by men compounds these problems of definition.

It is only when the legitimacy of art by and for women emerges that the aesthetic images of women will change. The process of developing individuation in women's art is slow and indirect. The fabrication of animals and birds for popular sale is the first step among the contemporary Bemba potters. Further innovations may also arise in textiles and painting. As a nontraditional art form that uses symbolically "female" or soft materials, painting may be an area into which the newly educated women of Central Africa will move. The promise of one Lusaka artist to train his daughters in his own profession may begin an experiment far beyond the limits that he anticipated by opening up a new dimension of selfexpression in popular painting. These changes, however, will only occur on a larger social and cultural scale once Central African societies openly acknowledge an increasing diversity in the public images that women may come to assume. A broader awareness of the gap between popular arts by and about women in Africa should provide a stimulus to re-examine the gender-linked themes and barriers in art production cross-culturally.

\section{NOTES}

Acknowledgments. I would like to thank the Wenner-Gren Foundation, which supported my work in the field during the period when these materials were collected. A comparative discussion of the American case is found in Goffman (1977:301-331).

Photo Credits. All photos included herein are by the author.

${ }^{1} \mathrm{Cf}$. the studies of traditional carving and male political power in Fraser and Cole (1972).

${ }^{2}$ The shape of the pot as a rounded container might be viewed as an archetypal women's symbol.

${ }^{3}$ See Turner (1967:151-277). This sexual segregation is reciprocal. Women's arts in general are guarded with equal secrecy from noninitiates and males in general. However, selected men must make women's masks and emblems among the Bemba, whereas the opposite is less frequently the case.

${ }^{4}$ Here $1 \mathrm{am}$ using aesthetic in the narrow sense as distinguished from the instrumental purposes of the object (Maquet 1971:6-9). However, the character of all the contemporary art products as selfexpressions, often with revitalized ritual intent, suggests that this Western definition of the aesthetic be reassessed.

${ }^{5} \mathrm{Cf}$. Szombati-Fabian and Fabian's characterization of the mami wata as a "totalizing symbol" (1976:5). Totalization, as used by Sartre, refers to the transcending of conflicting tendencies by including them as elements in a new whole. The mami wata is a totalizing symbol, because it transcends the contradictions between African, Asian and European cultural traditions to make a unifying statement that is relevant for the present, because it combines contradictory views of womanhood, and because it unifies the appreciation of itself as an art object with the broader purposes of the client.

${ }^{6} \mathrm{~A}$ structuralist analysis might thus see them as representing the opposition between nature and culture (Lévi-Strauss 1966:135-136). But this opposition only appears when considering the paintings as a whole. It might not be noticed by the individual client.

${ }^{7}$ In this sense, the mami wata does not involve sympathetic magic that operates to destroy an individual. However, the possession of the painting is virtually the possession of a magical charm or amulet.

${ }^{8}$ Daix (1975) examines the historical evidence regarding the putative influence of African sculpture on Picasso in 1905-06. He concludes that both a return to Iberian traditional forms and exposure to West African sculpture contributed sources of inspiration to Picasso at that time.

"Borrowing the generalized term "figuratist," denoting any portrait or realistic rendering in which figures are still visible, the Kanyama art circle dubbed themselves the New Figuratists.

10 The black velvet painters were concerned with making even their fictive portraits almost personally identifiable. As portrait painters, they stressed individuation of content, though not of style. 


\section{REFERENCES CITED}

Daix, Pierre

1975 Picasso et l'art nègre. In Art nègre et civilisation de l'universel. Anon. ed. Dakar: Les Nouvelles Editions Africaines.

D'Azevedo, Warren L., ed.

1973 The Traditional Artist in African Societies. Bloomington: Indiana University Press.

Dimock, Edward C., Jr.

1961 Manasha-Goddess of Snakes. University of Chicago Committee on Southern Asian Studies, Reprint Series, No. 13.

Drewal, Henry

1977 The New Faces of African Art: European, Indian, and African Imagery in the Ritual Forms of Mammy Wata. Unpublished manuscript.

Fraser, Douglas, and Herbert M. Cole, eds.

1972 African Art and Leadership. Madison: University of Wisconsin Press.

Goffman, Erving

1977 The Arrangement of the Sexes. Theory and Society 4(3): 301-331.

Hansen, Karen Tranberg

1975 Married Women and Work: Expectations from an Urban Case Study. African Social Research 20:777-799.

Jules-Rosette, Bennetta

1977 Cultural Transformation in Urban Africa: Indigenous Religions and Popular Art as Changing Expressive Forms. Paper presented at the MEA Conference on Transformation in PostColonial Africa, sponsored by Prof. Elliott Skinner and Prof. Pearl T. Robinson, African-American Scholars Council, Washington, D.C., May. To appear in Cultural Transformation in
Post-Colonial Africa. Elliott Skinner and Pearl T. Robinson, eds. (forthcoming).

Kavolis, Vytautas

1967 Artistic Expression: A Sociological Analysis. Ithaca: Cornell University Press.

Lévi-Strauss, Claude

1966 The Savage Mind. Chicago: University of Chicago Press.

Maquet, Jacques

1971 Introduction to Aesthetic Anthropology. New York: Addison-Wesley.

Mayer, Philip, with Iona Mayer

1971 Townsmen or Tribesmen. Cape Town: Oxford University Press.

Richards, Audrey I.

1956 Chisungu. London: Faber and Faber.

Sartre, Jean-Paul

1976 Critique of Dialectical Reason. Alan Sheridan-Smith, trans. London: NLB.

Szombati-Fabian, Ilona, and Johannes Fabian

1976 Art, History, and Society: Popular Art in Shaba, Zaire. Studies in the Anthropology of Visual Communication 3:1-21.

Tuchman, Gaye

1975 Woman and the Creation of Culture. In Another Voice: Feminist Perspectives on Social Science and Social Life. Marcia Millman and Rosabeth Moss Kanter, eds. Garden City: Anchor Books.

Turner, Victor W.

1967 The Forest of Symbols. Ithaca: Cornell University Press. Willett, Frank

1972 Ife, the Art of an Ancient Nigerian Aristocracy. In African Art and Leadership. Douglas Fraser and Herbert M. Cole, eds. Madison: University of Wisconsin Press. 